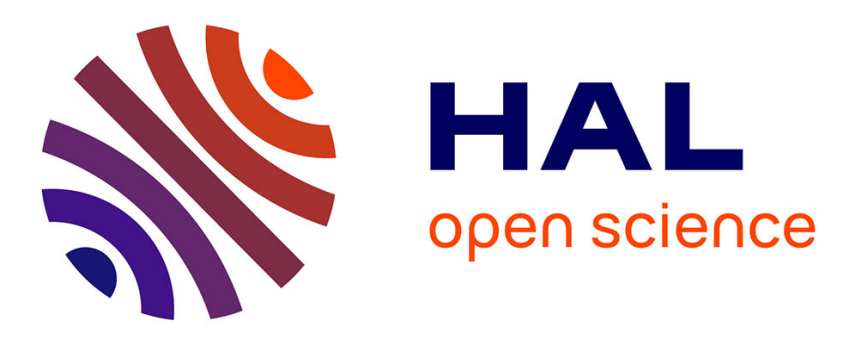

\title{
New paradigms in the exploitation of Mesolithic shell middens in Atlantic France: The example of Beg-er-Vil, Brittany
}

Catherine Dupont, Grégor Marchand

\section{- To cite this version:}

Catherine Dupont, Grégor Marchand. New paradigms in the exploitation of Mesolithic shell middens in Atlantic France: The example of Beg-er-Vil, Brittany. Quaternary International, 2021, 584, pp.5971. 10.1016/j.quaint.2020.09.043 . hal-03009965

HAL Id: hal-03009965

https://hal-univ-rennes1.archives-ouvertes.fr/hal-03009965

Submitted on 18 Nov 2020

HAL is a multi-disciplinary open access archive for the deposit and dissemination of scientific research documents, whether they are published or not. The documents may come from teaching and research institutions in France or abroad, or from public or private research centers.
L'archive ouverte pluridisciplinaire $\mathbf{H A L}$, est destinée au dépôt et à la diffusion de documents scientifiques de niveau recherche, publiés ou non, émanant des établissements d'enseignement et de recherche français ou étrangers, des laboratoires publics ou privés. 


\title{
New Paradigms in the Exploitation of Mesolithic Shell Middens in Atlantic France: the example of Beg-er-Vil, Brittany
}

\author{
Catherine Dupont and Grégor Marchand
}

CNRS UMR 6566 CReAAH (Centre de Recherche en Archéologie, Archéosciences, Histoire), Université de Rennes, Campus Beaulieu, 263 avenue Général Leclerc, bât. 24-25 CS74205, 35042 Rennes Cedex, France, catherine.dupont@univ-rennes1.fr, gregor.marchand@univ-rennesl.fr

\begin{abstract}
The Atlantic coast of north-west France is one of the classic shell-midden regions of the European Mesolithic, made famous by the excavations of Téviec and Hoedic in the first half of the $20^{\text {th }}$ century. At this time, there was a lack of interest in the food refuse component of shell middensBy the end of the 1990's new study methods and techniques had also contributed to a better description of the varied activities of these coastal populations. In Atlantic France, new excavations have demonstrated that shell middens are not a site type but rather one of a variety of stratigraphic units that make up the total settlement pattern. Our perception of the Mesolithic hunter-gatherers of the French Atlantic coast has now changed from a population pre-occupied with day-to-day survival and forced to eat shellfish out of necessity, to fisher-hunter-gatherers involved in varied activities. Their knowledge of marine biotopes is revealed by the diversity of marine animals dedicated to food, but also by other raw materials collected in high tide marks, including flint or shells devoid of flesh. The last ones give us an access to the symbolic sphere. These future personal ornaments were clearly and carefully selected on the beach for this purpose independently of alive ones.
\end{abstract}

Keywords: Mesolithic, maritime fisher-hunter-gatherers, shell middens, dwelling structures, human burials 


\section{Diversity of paradigms to study the shell middens in Atlantic Europe}

The Atlantic coast of north-west France is one of the classic areas for European shell midden research, beginning with the excavation of Téviec and Hoedic in the first half of the twentieth century (Péquart et al., 1937; Péquart et Péquart 1954), when investigations focused on human burials in shell midden deposits. The focus of archaeologists on such sites evolved this last century under the influences of other disciplines, other archaeological settlements and other countries.

Past studies of Mesolithic Atlantic European shell middens have not always placed human populations at the centre of their research interest as other objectives took precedence in this type of site among scholars or researchers from different disciplines. The changing nature of shell midden studies reflects the preoccupations of the time and contributes to the overall understanding of these very special sites. Early work on Mesolithic Atlantic European shell middens sought to describe the composition of these diversified accumulations of archaeological materials (ecofacts and artefacts; Grieve, 1874; Andersen and Johansen, 1986) to describe past faunal and floral biodiversity with a focus on the evidence recovered for plants and animals. Shell middens became important in Mesolithic studies following the publication of John Lubbock's enlightening work on Danish kjokkenmöddinger (Lubbock, 1861). This now iconic link between shell middens and the Atlantic Mesolithic was connected to a certain form of romanticism, namely of populations lost at the confines of continents or beachcombers living on marine resources (Clark, 1952; Milner and Woodman, 2007). The density of these sites has even prompted researchers to refer at times to a "shell midden culture" (Breuil and Zbyszweski, 1947; Roche, 1972, 1983; Marchand, 2015). However, this unitary notion was often rather hastily overlooked. Mesolithic shell middens have thus been studied in quite different ways depending on the questions developed at national levels (Lacaille, 1954; Mellars, 1978; Fischer, 1995; Andersen, 2000; González Morales and Clark, 2004; McCartan et al., 2009; Bailey et al., 2013; Marchand, 2014, Gutiérrez-Zugasti et al., 2011). In Spain, it was the lithic assemblages (Sanz de Sautuola, 1880) that triggered early research into shell middens, as these artefacts offered the possibility to propose a relative chronological classification of sites. In Portugal (Oliveira, 1888-1889; Pereira da Costa, 1865; Ribeiro, 1884), the presence of human skeletons in shell middens led researchers to consider 
them as necropolises as well as dumps composed mainly of shells (Roksandic and Jackes, 2014, p. 113).

In France, where Palaeolithic cave archaeology dominates perceptions of Prehistory, shell middens were largely neglected. The shell middens were first described as "strato-types" intended to define a pre-Neolithic period (Du Châtellier, 1881; Bénard Le Pontois, 1929). They were then scrupulously studied to provide relationships between the different stages of research (Péquart and Péquart 1928, 1929, 1931, 1933a, 1933b, 1934, 1935), with the ultimate aim of writing a monograph that explored all the technical, racial and spiritual aspects of these populations (Péquart et al., 1937; Péquart and Péquart, 1954). The good preservation of organic materials at sites below dunes and in layers with low acidity, allowed for the first radiocarbon dating to take place, and the shelly levels thus served as a timely chronological framework for typological or technological classifications (Kayser, 1985, 1992; Kayser and Bernier, 1988; Marchand, 1999). This led to a renewal of work on shell middens in France, linked to questions raised by North American social anthropology at that time. After the general rehabilitation of hunter-gatherers (Lee, 1968; Sahlins, 1974), it became apparent that certain specialised maritime economies generated surpluses by means of extremely elaborate technical systems, and that social hierarchies emerged through competition for prestige. These factors, combined with high population densities, set apart this category of "maritime huntergatherers" (Yesner, 1980; Erlandson, 1988; Binford, 2001; Sassaman, 2004; Kelly, 2007). The application of these new theoretical perspectives to the Mesolithic groups shed new light on a period then conceived as twilight of the Paleolithic. Because they testified precisely to the accumulation of marine products likely to be stored, the shell middens benefited from this positive re-evaluation of hunter-gatherer communities prior to the Neolithic period. (Testart, 1982; Price and Brown, 1985; Zvelebil, 1986). This research adopted a strong processual leaning, with a marked orientation towards taking into account, for example, the economic value of these shellfish deposits (Straus, 1981, 2004; Arnaud, 1989).

The necropolises of Téviec and Hoedic were then periodically studied in the search for ornaments (Taborin, 1971, 1974; Newell et al., 1990; Rigaud, 2011), funeral adornments and tools (Schulting, 1996), or dietary practices studied through carbon and nitrogen stable isotope analysis (Schulting and Richards, 2001) on the basis of old excavations remains. The exceptional preservation conditions also attracted faunal specialists at a time when French archaeozoology was undergoing profound methodological renewal (Tresset, 2000, 2002, 2003, 2005a; Gruet, 2002; Dupont and Gruet, 2005; Dupont, 2006; Dupont et al., 2009, 
2010). Such combination of archaeological and paleo-environmental disciplines were initiated in other shell middens of the Atlantic Europe earlier (Mellars, 1978, 1987; Andersen and Johansen, 1986) or at the same time as in France (Woodman, 2009; Bicho et al., 2010; O’Sullivan and Breen, 2011; Andersen, 2013; Gutiérrez-Zugasti et al., 2013, 2014; Bicho et al., 2015; Arias et al., 2017; Moe Astrup et al., 2019). The descriptions of shell middens in Brittany during the first half of the $20^{\text {th }}$ century were influenced by the image associated with prehistoric populations, as the past excavations at Téviec and Hoedic focused on human bones and ignored the marine molluscs.

In this paper, we evaluate the nature of the maritime economies from the late Mesolithic period on the eve of the major social and economic changes that accompanied Neolithisation. First, we set out how the investigators over the past 100 years described French Mesolithic shell middens, showing how the nature of interpretations and methods has altered with changing paradigms in archaeology. This is providing a context for the re-evaluation of the archaeological evidence from Brittany that has been uncovered since the end of the nineteenth century, including the excavations of the shell middens at Téviec and Hoedic in the 1920's and 1930's (Péquart et al., 1937; Péquart et Péquart 1954). In this aim, we focus on the way recent methodological developments have contributed to interpretations following the sevenyear long excavations at Beg er Vil, in 2012- 2018. We discuss the significance of these results with respect to the impact of different sampling methods on data recovery; issues of shell-midden formation and preservation; and interpretation of spatial organisation, and of the use of marine molluscs.

\section{Contribution and limitations of the first descriptions of shell midden contents in Brittany}

Along the French Atlantic coast, the last transgression covered a large part of Southern France south of the Garonne, with dunes, as well as swamps that have now become dry marshes between the Loire and the Garonne (Verger, 2005). The four main shell middens known in France (Téviec, Hoedic, Beg-er-Vil and Beg-an-Dorchenn; Fig. 1) are located in the northwest of the region on coastlines exposed to Atlantic swells. They are all currently being eroded by the sea. Sand dunes covered these archaeological sites and partly contributed to their conservation (Dupont, 2006). Others, such as those of Saint-Gildas largely disappeared 
as a result of cliff erosion before they could be analysed (Dupont and Marchand, 2008) though surviving fragments provide a truncated vision of the way of life of these prehistoric populations (Dupont and Marchand, 2008).

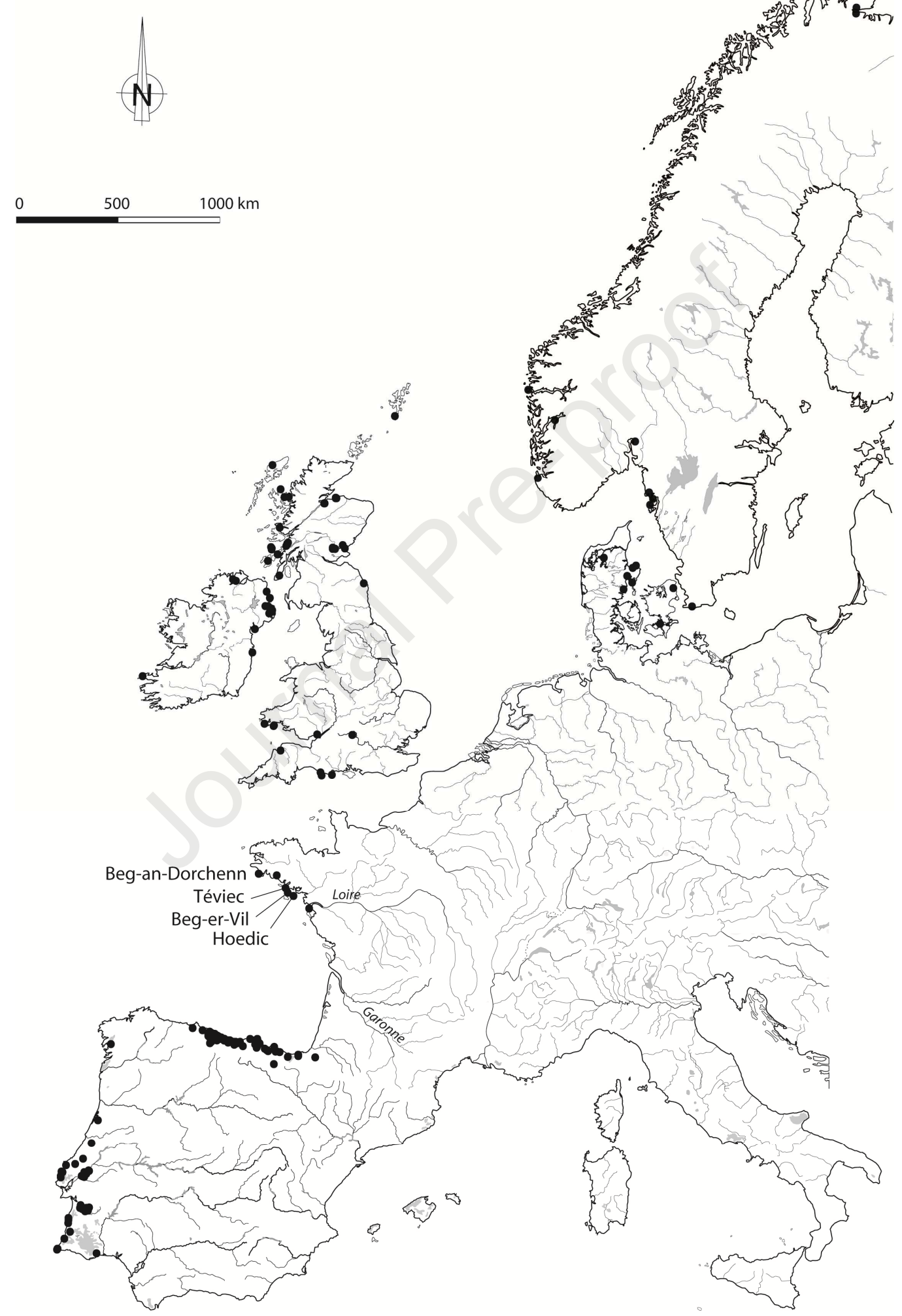

Fig. 1. Distribution of Mesolithic shell middens on the European seaboard and sites mentioned in the paper (C. Dupont CNRS) 
Beg-an-Dorchenn (formerly known as la Torche) and Téviec were the first sites to be described, at the end of the nineteenth century (Du Châtellier, 1881;Gaillard, 1885; Table 1, Fig. 2). Primarily on account of the mammal remains, these shell accumulations were identified as kitchen waste. Du Châtellier indicated the presence of numerous shells, charcoals and flint artefacts in Beg-an-Dorchenn. He also described the composition of the shell midden, citing fish and marine molluscs among the main resources as well as birds and mammals. He linked the lithic industry to animal exploitation and suggested that arrows with flint arrowheads were used to hunt waders. But his principal focus was on what he considered to be artefacts notably flint tools, bone point fragments, bone awls and a shell pendant ( $\mathrm{Du}$ Châtellier, 1881, p. 181). The limpet was listed as the most abundant shell, but he also cited oysters (Ostrea edulis), razor shells (Solen sp.), scallops (Mimachlamys sp.), in particular the great scallop (Pecten maximus), and carpet shells (Ruditapes decussatus). This list seems to be oriented towards the shellfish most valued by his contemporaries and does not mention the numerous gastropods present in prehistoric levels (including the periwinkle Littorina littorea or the thick top shell Phorcus lineatus).

F. Gaillard (Gaillard, 1885, p. 409) indicated the presence of innumerable shells associated with animal bones as well as flint fragments, hammers and a worked bone and fragments of whale bone. His short description reflects his aim, which was to discover indicators of the presence of dolmen builders. For this reason, he did not dwell on the composition of the shell midden itself. It is important to underline the state of mind of some researchers at that time and the negative image associated with prehistoric populations. In one of F. Gaillard's correspondences, the term "savage" is used to refer to individuals who could have used whale bone as a hammer (Gaillard, 1885, p. 411).

A renewed interest in 1920s and 1930s (Fig. 2, Table 1) led to a new excavation at the Began-Dorchenn shell midden between 1920 and 1926, (Bénard Le Pontois, 1929) with shells, small bones and "badly" knapped flint being described. Lithics were described as "knapped in a mediocre way", with "a few more or less straight blades, several vague arrowheads next to mediocre scrapers" (Bénard Le Pontois, 1929, p.44). Above the prehistoric shell midden, he identified a second, more recent heap, though no stratigraphic distinction was made (Tresset, 2003, 2005b). 
Journal Pre-proof

\begin{tabular}{|c|c|c|c|c|c|c|}
\hline $\mathbf{N}^{\circ}$ & Study & Téviec & Hoedic & $\begin{array}{c}\text { Beg-an- } \\
\text { Dorchenn }\end{array}$ & $\begin{array}{c}\text { Beg- } \\
\text { er-Vil }\end{array}$ & Reference \\
\hline 1 & Domestic features & $\mathrm{X}$ & $\mathrm{X}$ & $\mathrm{X}$ & $\mathrm{X}$ & $\begin{array}{l}\text { Péquart et al., 1937, Péquart and } \\
\text { 1954; Kayser and Bernier, 1988; } \\
\text { Marchand, 2014, } 2017\end{array}$ \\
\hline 2 & Shell ornaments & $\mathrm{X}$ & $\mathrm{X}$ & & & Taborin, 1971,1974 \\
\hline 3 & Radiocarbon dating & $\mathrm{X}$ & $\mathrm{X}$ & $\mathrm{X}$ & $\mathrm{X}$ & $\begin{array}{l}\text { Kayser, 1985; Schulting and } \\
\text { Richards, 2001; Marchand et al, } \\
2009,2016\end{array}$ \\
\hline 4 & $\begin{array}{l}\text { Isotopic analyses on } \\
\text { bones }\end{array}$ & $\mathrm{X}$ & $\mathrm{X}$ & & & $\begin{array}{l}\text { Schulting, 1996; Schulting and } \\
\text { Richards, } 2001\end{array}$ \\
\hline 5 & $\begin{array}{l}\text { Lithic studies (typology } \\
\text { and technology) }\end{array}$ & $\mathrm{X}$ & $\mathrm{X}$ & $\mathrm{X}$ & $\mathrm{X}$ & Marchand, 1999 \\
\hline 6 & Mammals & & & $\mathrm{X}$ & & Tresset, 2000 \\
\hline 7 & Crabs and barnacles & & & $\mathrm{X}$ & $\mathrm{X}$ & $\begin{array}{l}\text { Gruet, 2002; Gruet in Dupont et } \\
\text { al., } 2010\end{array}$ \\
\hline 8 & Birds & $\mathrm{X}$ & $\mathrm{X}$ & & $\mathrm{X}$ & Tresset, 2002, 2005a \\
\hline 9 & Marine molluscs & $\mathrm{X}$ & $\mathrm{X}$ & $\mathrm{X}$ & $\mathrm{X}$ & Dupont, 2003, 2006 \\
\hline 10 & Marine reservoir effect & $\mathrm{X}$ & $\mathrm{X}$ & $\mathrm{X}$ & $\mathrm{X}$ & Marchand et al., 2009 \\
\hline 11 & Charcoal & & & $\mathrm{X}$ & 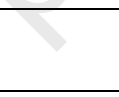 & $\begin{array}{l}\text { Marguerie and Carrion Marco in } \\
\text { Dupont et al., } 2010\end{array}$ \\
\hline 12 & Fish & & & $\mathrm{X}$ & $\mathrm{X}$ & $\begin{array}{l}\text { Desse-Berset in Dupont et al., } \\
\text { 2010; Marchand et al., } 2016\end{array}$ \\
\hline 13 & Palynology & & & $\theta$ & - & $\begin{array}{l}\text { Marguerie } \\
\text { unpublished } 2012\end{array}$ \\
\hline 14 & Phytoliths & & & & - & $\begin{array}{l}\text { Delhon } \\
\text { unpublished } 2013\end{array}$ \\
\hline 15 & Paleoparasitology & & & & - & $\begin{array}{l}\text { Le Bailly } \\
\text { unpublished } 2013\end{array}$ \\
\hline 16 & $\begin{array}{l}\text { Functional analysis of } \\
\text { lithics }\end{array}$ & $X$ & & $\mathrm{X}$ & $\mathrm{X}$ & $\begin{array}{l}\text { Guéret et al., 2014; Calvo Gómez } \\
2018\end{array}$ \\
\hline 17 & Traceology on shells & $\mathrm{X}$ & & & $\mathrm{X}$ & $\begin{array}{l}\text { Cuenca Solana } \\
\text { unpublished } 2015\end{array}$ \\
\hline 18 & Physical anthropology & $\mathrm{X}$ & $\mathrm{X}$ & & & Boulestin, 2016 \\
\hline 19 & Topo-bathymetric & & & & $\mathrm{X}$ & $\begin{array}{l}\text { Stephan in Marchand et al., 2016, } \\
2018\end{array}$ \\
\hline 20 & $\begin{array}{l}\text { Micromorphology } \\
\text { (geoarchaeology) }\end{array}$ & & & & $\mathrm{X}$ & $\begin{array}{l}\text { Onfray in Marchand et al., 2016, } \\
2018\end{array}$ \\
\hline 21 & Bone tool studies & $\mathrm{X}$ & $\mathrm{X}$ & & $\mathrm{X}$ & $\begin{array}{l}\text { David, 2017; Poissonnier and } \\
\text { Kayser, 1988; Marquebielle } \\
\text { unpublished } 2019\end{array}$ \\
\hline 22 & pH Soil acidity & & & & $\mathrm{X}$ & $\begin{array}{l}\text { Querré and Le Bannier in } \\
\text { Marchand et al., } 2018\end{array}$ \\
\hline 23 & $\begin{array}{l}\text { Macrolithic studies } \\
\text { (typology and } \\
\text { technology) }\end{array}$ & $\mathrm{X}$ & $\mathrm{X}$ & $\mathrm{X}$ & $\mathrm{X}$ & Marchand et al., 2019 \\
\hline 24 & $\begin{array}{l}\text { X-Ray fluorescence } \\
\text { spectrometry on soil }\end{array}$ & & & & $\mathrm{X}$ & $\begin{array}{l}\text { Querré and Le Bannier in } \\
\text { progress }\end{array}$ \\
\hline 25 & DNA on human bones & $\mathrm{X}$ & $\mathrm{X}$ & & & Jakobbson in progress \\
\hline 26 & DNA on sediments & & & & - & $\begin{array}{l}\text { Ollivier } \\
\text { unpublished } 2020\end{array}$ \\
\hline
\end{tabular}

Table 1. Disciplines involved in studies of the main French Mesolithic shell middens (X: analysed site, - : negative result) 


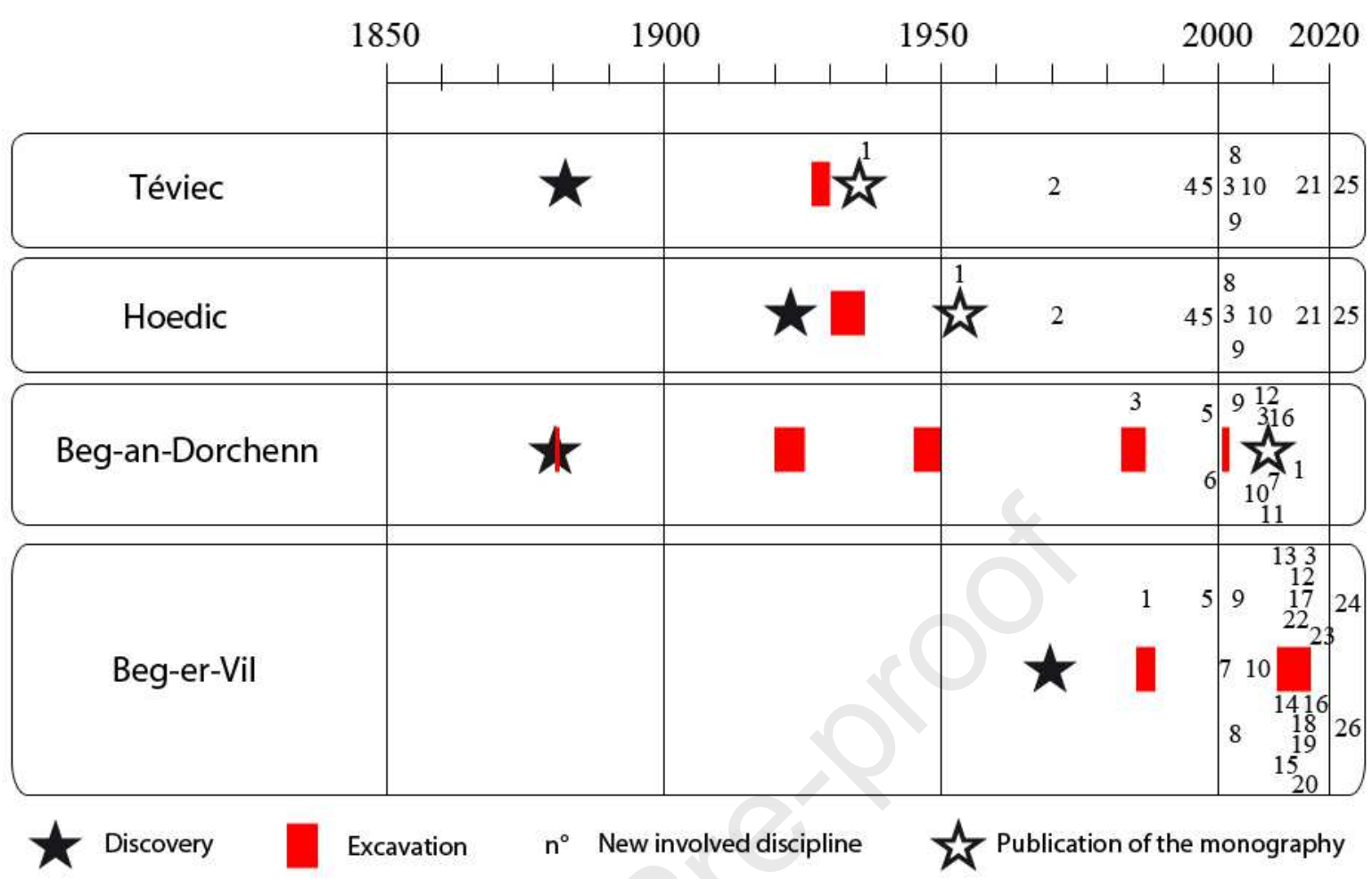

Fig. 2. Periods of discovery, excavation and studies of the main French Mesolithic shell middens (numbers correspond to involved disciplines detailed in table 1)

In such a context, the focus on the shell middens of Téviec and Hoedic following the excavations of the Péquarts from 1928 to 1930 for the former, and from 1931 to 1934 for the latter (Péquart, et al., 1937; Péquart and Péquart, 1954), is remarkable. Skeletons began to overshadow their associated structures and brought renown to the sites of Téviec and Hoedic. Of the ten publications by the Péquarts seven mention the necropolises and only one quotes the shell midden or "kjökkenmödding" (Péquart and Péquart 1928, 1929, 1930, 1931, 1933a, 1933b, 1934, 1935, 1954; Péquart et al., 1937). Therefore, despite the quality of the Péquarts' excavations for the time, their focus on burials led to the neglect of the archaeological 'sediment' (Table 2).

\begin{tabular}{|l|l|}
\hline Archaeological choices & \multicolumn{1}{c|}{ Consequences } \\
\hline Main focus on burials & $\begin{array}{l}- \text { Lack of data on the composition of the shell } \\
\text { midden } \\
- \text { Only ornaments linked to the body were collected } \\
- \text { No data from around the shell midden } \\
- \text { Distortion of the quantity of animals remains } \\
\text { connected to food and the symbolic world }\end{array}$ \\
\hline No precise positioning of artefacts & $\begin{array}{l}\text { - No precise spatial data for faunal remains } \\
- \text { Difficult to identify objects in perishable }\end{array}$ \\
\hline
\end{tabular}




\begin{tabular}{|c|c|}
\hline & $\begin{array}{l}\text { materials (clothes, boxes, personal objects...) } \\
\text { - Lack of data on links between the burials, the } \\
\text { dwelling and the formation of the shell midden }\end{array}$ \\
\hline $\begin{array}{l}\text { Selective sorting in the field for lithic artefacts, large } \\
\text { bones, small perforated shells and mainly for the burials }\end{array}$ & $\begin{array}{l}\text { - Distorted vision of artefacts: only large pieces } \\
\text { were collected } \\
\text { - Faunal remains from burials are over-represented } \\
\text { - Only the more abundant ornaments were } \\
\text { identified } \\
\text { - The composition of the shell midden inside the } \\
\text { burials is unknown } \\
\text { - Impossible to know if flint was knapped in the } \\
\text { shell midden }\end{array}$ \\
\hline
\end{tabular}

Table 2- A distorted view of the Mesolithic shell middens of Téviec and Hoedic used as cemeteries due to early dates of excavation

Particular attention was paid to the faunal remains present in the vicinity of the human skeletons, which led to an over-representation of animals with symbolic significance compared to consumed animals (Tresset, 2005a, 2005b). Although much of the sediment, including that of the midden, was sieved, only the remains considered to be of interest by archaeologists at that time were preserved, namely perforated shells, flint arrowheads, human bones and large mammals. But our truncated vision of these sites is not solely due to excavation methods during the first half of the twentieth century, it is also linked to technical constraints dictated by the equipment used at that time.

Before the 1980s, the spatial recording of artefacts was not common and only the proximity of an artefact to specific skeletons was mentioned. This limits the description of the way in which the thousands of elements of adornment associated with each skeleton were worn (Laporte and Dupont, 2019). Our knowledge of the Mesolithic populations from the shell middens of Téviec and Hoedic is concentrated more on the burials than on the site as a whole. This choice is clearly linked to the focus on skeletons, but also to the fact that excavators worked in isolation, as other archaeological disciplines were poorly developed (Fig. 2; Table $1)$.

The increase in the number of related disciplines involved in the study of shell middens from the end of the twentieth century onwards is the result of a combination of several factors. These include, in France in particular, a relatively late scientific interest for the Epipalaolithic/ Mesolithic, a period firstly only defined as a transition between the Palaeolithic and the Neolithic (Pluciennik, 1998, p.63; Zvelebil, 1998, p.2). The professionalization of archaeology, linked in France to the natural science disciplines (Djindjian, 2016), began in the 
1960's. This relationship between archaeology and sciences evolved differently according to different countries and archaeological periods (Djindjian, 2016; Deschler-Erb, 2019).

\section{3 - The difficult evaluation of the real place of marine molluscs}

We compiled the data from the study of marine shells from the four Mesolithic shell middens excavated in north-western France to demonstrate the variable evidence according to time period (Table 3 ).

\begin{tabular}{|c|c|c|c|}
\hline $\begin{array}{l}\text { Archaeological sites } \\
\text { Manager of the } \\
\text { excavation } \\
\text { Date of excavation } \\
\text { Excavated surface }\end{array}$ & Excavation techniques involved with shells & Shells as food & $\begin{array}{l}\text { Shells as } \\
\text { ornaments }\end{array}$ \\
\hline $\begin{array}{c}\text { Téviec } \\
\text { M. and S.-J. Péquart } \\
\text { 1928-1930 } \\
324 \mathrm{~m}^{2}\end{array}$ & $\begin{array}{l}\text { Sieving and sorting in the field without water } \\
\text { (mesh unknown) }\end{array}$ & $\begin{array}{l}\mathrm{MNI}=130 \\
16 \text { species }\end{array}$ & $\begin{array}{l}\text { MNI=6 } 987 \\
12 \text { species }\end{array}$ \\
\hline $\begin{array}{c}\text { Hoedic } \\
\text { M. and S.-J. Péquart } \\
1931-1934 \\
200 \mathrm{~m}^{2}\end{array}$ & $\begin{array}{l}\text { Sieving and sorting in the field without water } \\
\text { (mesh unknown) }\end{array}$ & $\begin{array}{l}\mathrm{MNI}=265 \\
20 \text { species }\end{array}$ & $\begin{array}{l}\mathrm{MNI}=5066 \\
17 \text { species }\end{array}$ \\
\hline $\begin{array}{l}\text { Beg-an-Dorchenn } \\
\text { O. Kayser } \\
1984-1988 \\
53 \mathrm{~m}^{2}\end{array}$ & $\begin{array}{l}\text { Sieving and sorting in the field without water } \\
\qquad(\text { mesh } 5 \mathrm{~mm})\end{array}$ & $\begin{array}{l}\mathrm{MNI}=58 \\
10 \text { species }\end{array}$ & $\begin{array}{l}\mathrm{MNI}=18 \\
5 \text { species }\end{array}$ \\
\hline $\begin{array}{l}\text { Beg-an-Dorchenn } \\
\text { C. Dupont and G. } \\
\text { Marchand } \\
2001 \\
1 \mathrm{~m}^{2}\end{array}$ & $\begin{array}{l}\text { Sieving and sorting in the laboratory with fresh } \\
\text { water (mesh } 4 \text { and } 2 \mathrm{~mm})\end{array}$ & $\begin{array}{l}\text { MNI=13 } 324 \\
31 \text { species }\end{array}$ & $\begin{array}{l}\mathrm{MNI}=11 \\
2 \text { species }\end{array}$ \\
\hline $\begin{array}{l}\text { Beg-er-Vil } \\
\text { O. Kayser } \\
1985-1988 \\
22 \mathrm{~m}^{2}\end{array}$ & $\begin{array}{l}\text { Sieving in the field without water (mesh } 5 \mathrm{~mm} \text { ) } \\
\text { In 2001: sieving and sorting in the laboratory with } \\
\text { fresh water (mesh } 4 \text { and } 2 \mathrm{~mm} \text { ) }\end{array}$ & $\begin{array}{l}\text { MNI }=3769 \\
\left(4 \mathrm{~m}^{2}\right) \\
23 \text { species } \\
\left(4 \mathrm{~m}^{2}\right)\end{array}$ & $\begin{array}{l}\mathrm{MNI}=8\left(4 \mathrm{~m}^{2}\right) \\
2 \text { species }\left(4 \mathrm{~m}^{2}\right)\end{array}$ \\
\hline $\begin{array}{l}\text { Beg-er-Vil } \\
\text { G. Marchand and C. } \\
\text { Dupont } \\
\text { 2012- } 2018 \\
180 \mathrm{~m}^{2}\end{array}$ & $\begin{array}{c}\text { Sieving in the field first with marine water and } \\
\text { secondly with fresh water (mesh } 4 \text { and } 2 \mathrm{~mm} \text { ) } \\
\text { Sorting in the laboratory }\end{array}$ & $\begin{array}{l}\text { Shells as food } \\
\text { In progress } \\
34 \text { species }\end{array}$ & $\begin{array}{l}\text { Shells as } \\
\text { ornaments } \\
\text { In progress } \\
2 \text { species }\end{array}$ \\
\hline
\end{tabular}

Table 3. Distortions in the diversity and quantity of shells linked to the dates of excavations (MNI: Minimum Number of Individuals)

The data from Téviec and Hoedic come from the publications of the monographs (Péquart et al., 1937; Péquart and Péquart, 1954), while the material deposited in the Carnac Museum provided information on the studies of ornaments (Taborin, 1974) and food remains (Dupont, 
2006). They immediately show a distortion between the published texts and the quantification of preserved material (Table 3). Indeed, in the publications, shells are considered to be abundant in the shell midden, but only one hundred and thirty shells were counted at Téviec, if the published data are cross-referenced with the material deposited at Carnac, compared to 265 at Hoedic. The identified ornaments (7,000 in Téviec and more than 5,000 in Hoedic) are particularly abundant and therefore present a totally misleading picture of the original composition of the archaeological deposits. Subsequent analyses at other Mesolithic sites have also shown that caution is called for and, in addition, that some shells with perforations were pierced after being abandoned on site (Dupont et al., 2010; Dupont, 2011). Species diversity for food remains is slightly higher at Téviec and Hoedic than for ornaments, but they do not attain the thirty or so species generally recorded at these coastal sites. This observation is undoubtedly linked to the sieving carried out in the field during excavations in the first half of the twentieth century, with direct sorting of the sieved sediments.

Similarly, the absence of archaeological shell specialists in the 1980s also had an impact on the sampling methods used in the field and on our knowledge of the Beg-an-Dorchenn and Beg-er-Vil shell middens (Kayser, 1985, 1987). The differences observed between these two sites excavated by $\mathrm{O}$. Kayser are related to differences in sampling strategies. At Beg-anDorchenn, the most representative shell species in the shell midden were treated separately, as were perforated specimens (Dupont et al., 2010). The same protocol was applied at Beg-erVil, although the remaining sediments were $100 \%$ dry sieved on $5 \mathrm{~mm}$ sieves (personal information 2019 O. Kayser). The absence of large perforated shells used as ornaments and found in burials during excavations should also be mentioned. On the Beg-er-Vil and Beg-anDorchenn shell middens, these were probably recovered when attachment ties were broken, unlike the small elements that are more difficult to find. This scenario explains the lower species diversity for ornaments recorded at Beg-an-Dorchenn and Beg-er-Vil.

The results of the 1980s' excavation in Beg-an-Dorchenn speak for themselves. Only 58 food shells were counted, along with 18 used as ornaments, for $53 \mathrm{~m}^{2}$ of excavated shell midden. This is what we have called the "shoebox syndrome". Shell middens of several hundred square metres reduced to several boxes do not in any way reflect the abundance of the original remains. The number of species is even lower than those described at Téviec and Hoedic. A one-square-metre survey of Beg-an-Dorchenn in 2001 sheds light on the distortions related to the methods used in the field. It not only shows that shells with food value were 
underestimated, but also that lost ornaments were largely overlooked (Table 3). The drastic increase in species diversity, which rose from 10 to 31 species, is clearly linked to the identification of fragile or small species that passed between sieve meshes during previous excavations (Dupont, 2006). Despite the small area surveyed in 2001 in Beg-an-Dorchenn, this field operation clearly represented a window of opportunity to gain new insights into these Mesolithic populations. It not only showed that the informative potential of marine molluscs had been hugely underestimated, but also that of fish, crustaceans, birds, mammals, charcoal and even the lithic industry (Dupont et al., 2010).

The entire sediment of Beg-er-Vil was dry sieved with a $5 \mathrm{~mm}$ mesh during excavations in the 1980s. However, only a few shell elements were set apart. Nonetheless, all the sediments were bagged and preserved. More than 10 years later, only the quarters of four square metres of the shell midden and the contents of structures identified as pits were sieved with 5 and 1 $\mathrm{mm}$ meshes. The largest mesh was completely sorted. Only a quick visual check was made on the smallest mesh to evaluate the homogeneity of waste. We were thus able to show that the main species visible in the midden, the mussel Mytilus edulis Linnaeus, 1758, was visually absent after sieving linked to sorting (Dupont 2006, Fig. 3). . This species, which has a thin and fragile shell, is characterized in Beg-er-Vil by a high rate of calcination which has accentuated its fragility. Although several thousand mussels were counted in Beg-er-Vil, none of them have been observed intact.

The underestimation of marine resources in the diet of coastal Mesolithic groups from Western France was also underlined by the gradual development of isotopic analyses conducted on Mesolithic burials (Schulting, 1996; Schulting and Richards, 2001). While these analyses can reveal the predominant protein dietary components (marine or terrestrial), they do not provide any details on the consumed species. In the same vein, archaeozoological analyses provide sporadic data on the diet but we do not know if these remains represent occasional meals or are part of the staple diet (Table 1). For this reason, we combined both scales of observation to determine whether the composition of shell middens was compatible with the isotopic analyses on human bones (Schulting et al., 2004; Dupont et al., 2007). Comparisons of these two types of analyses from Mesolithic shell middens in France, Scotland, Ireland and England showed both similar and complementary results, encouraging us to continue our sieving exploration of shelly layers. 


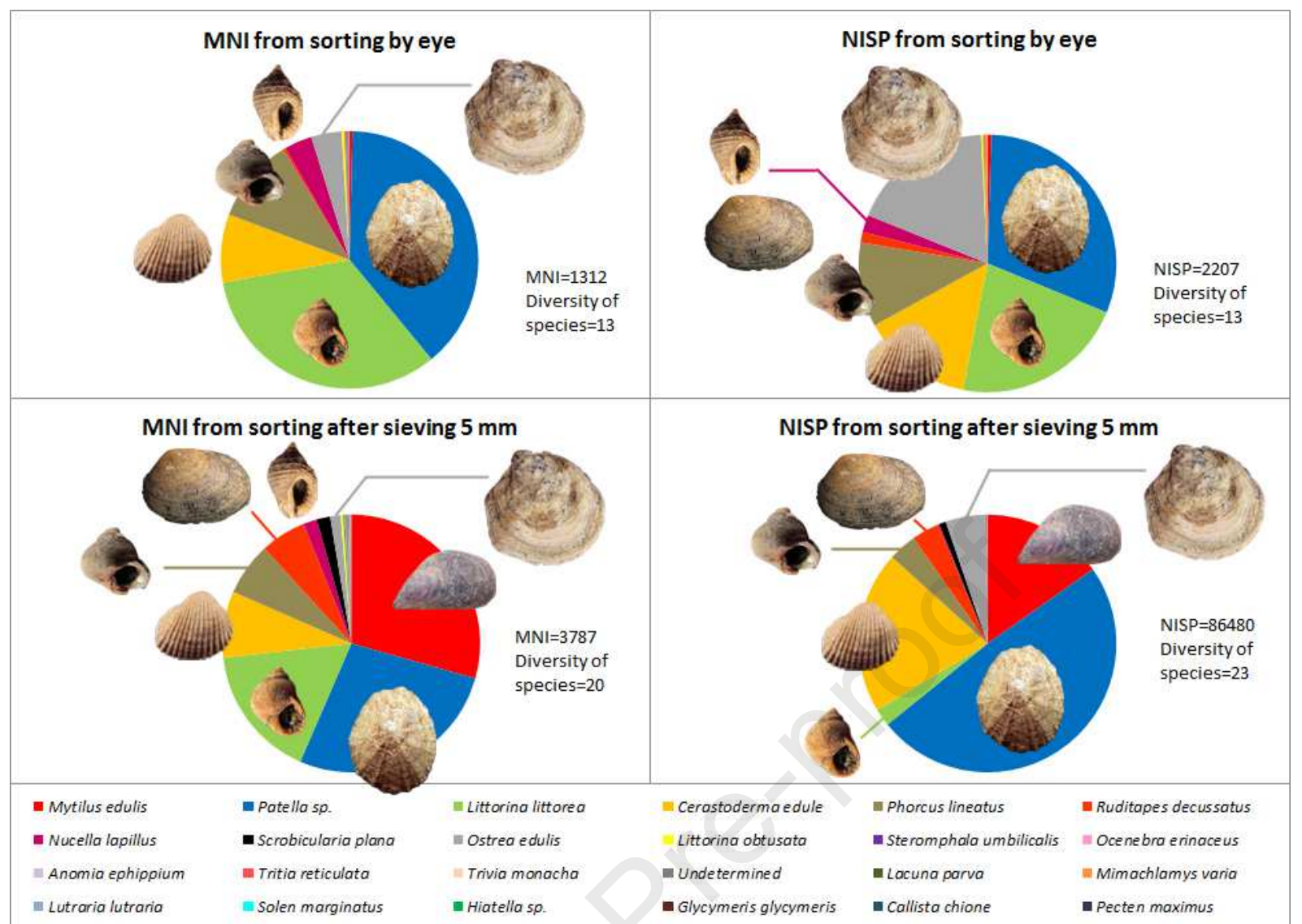

Fig. 3. The quantity, diversity and proportions of marine mollusc according to sampling methods. Experimentation on sediments from Beg-er-Vil 1980s' excavations (MNI: Minimum Number of Individuals; NISP: Number of Individual Specimens; CAD C. Dupont)

\section{Feedback after the Beg-er-Vil excavation}

\subsection{Stratigraphy and spatial organization of the site}

On the strength of the experiments linked to the empirical study of these shell middens, a new excavation was undertaken in Beg-er-Vil between 2012 and 2018 (Marchand et al., 2016, 2018; Table 1). The main themes we aimed to tackle were the stratigraphic links between the midden and some of the previously described domestic structures, such as pits and hearths. We also wished to explore the organization of the living space beyond the shell midden, which had often been neglected at the scale of the Atlantic coast of Europe, as in the Muge complex for example (Bicho et al. 2015).

The Mesolithic coastal habitat of Beg-er-Vil is located at the top of a rocky cliff (Fig. 4). This single level of occupation, estimated at $40 \mathrm{~cm}$ on average, owes its good preservation (Fig. 5) to a dune that covered it with a thickness of 0.50 to $2 \mathrm{~m}$. Most dates obtained for this level from twigs or burnt fruit fall within the same 7300/7200 BP range (uncalibrated; Marchand 
and Schulting, 2019; Fig. 6; Table 4). The combination of nine reliable site dates using Oxcal V. 4.3 gives the interval 8163-8057 cal BP (at $68.2 \%$ confidence). All of the archaeological operations took place in a surface area of $351 \mathrm{~m}^{2}$. A $22 \mathrm{~m}^{2}$ excavation had been carried out between 1985 and 1988 by O. Kayser in the shell deposit to the east of the site (Kayser and Bernier, 1988; Poissonnier and Kayser, 1988). The new field operation enabled an area of 158 $\mathrm{m}^{2}$ to be excavated in detail. The total extension of the shell level is estimated to be $130 \mathrm{~m}^{2}$, but its original spread cannot be evaluated since an unknown amount has been washed away.

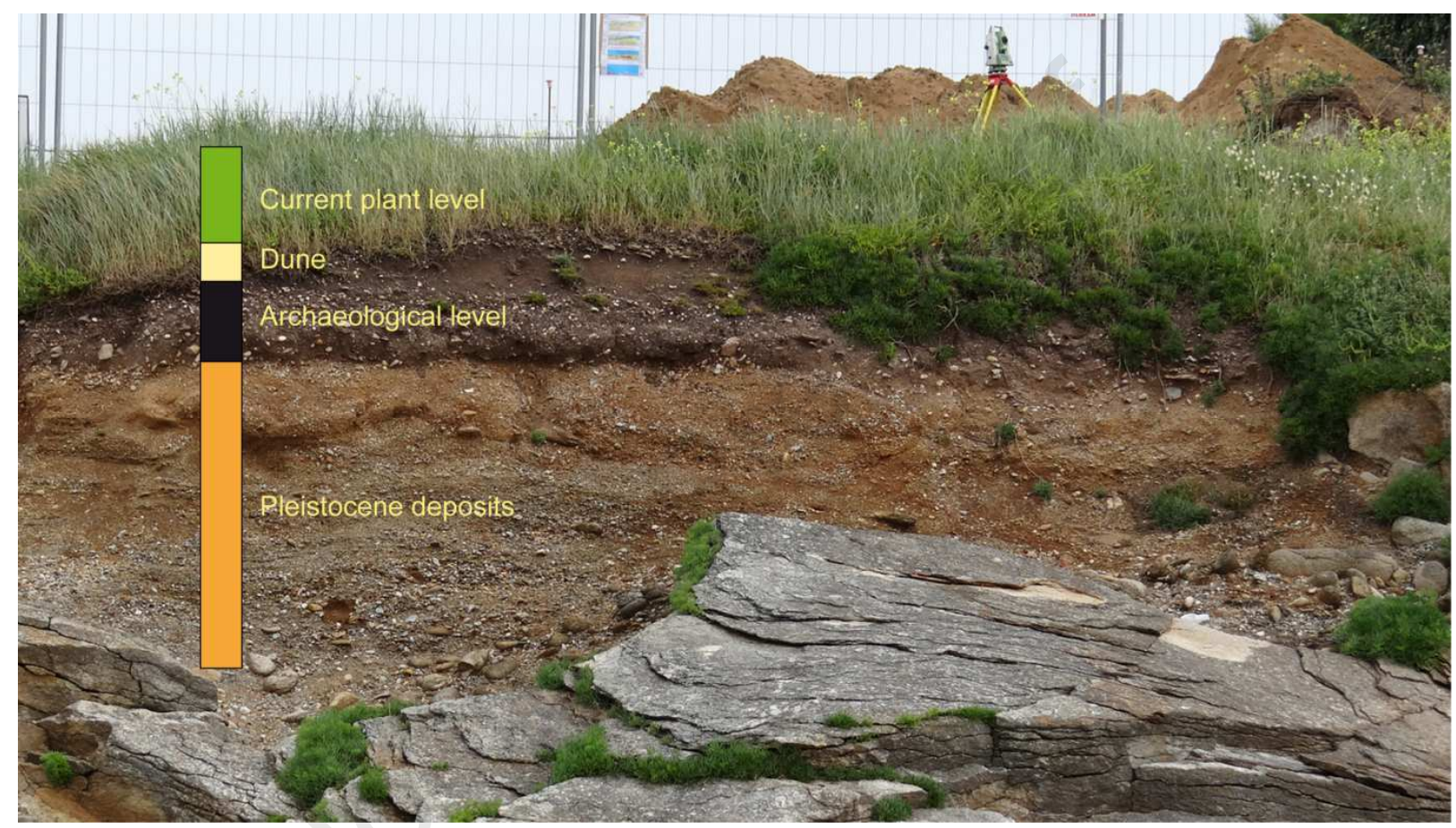

Fig. 4. General sedimentary succession seen in the natural cut at Beg-er-Vil (Quiberon, Morbihan France) (Photo: G. Marchand, CNRS).

A shell level to the west and a sandy peripheral zone to the east correspond to spatially differentiated activities. The two areas explored by the excavation lie on different slopes: the shells are spread over a slight slope towards the southwest, while further east the sandy level is almost horizontal. In the current state of research, the typo-technological characteristics of the lithic assemblage are not distinguishable in the two zones. The first is both a dumping zone and an activity area: several fireplaces indicate poorly-defined uses, that could be culinary, domestic, artisanal or religious. At $4 \mathrm{~m}$ east of the shellfish dump, small non-rolled blocks of stone from the substrate were implanted vertically in the ground, with a complex arrangement (parallel or orthogonal stones) suggesting wedges for stakes made of perishable material. 


\section{Journal Pre-proof}

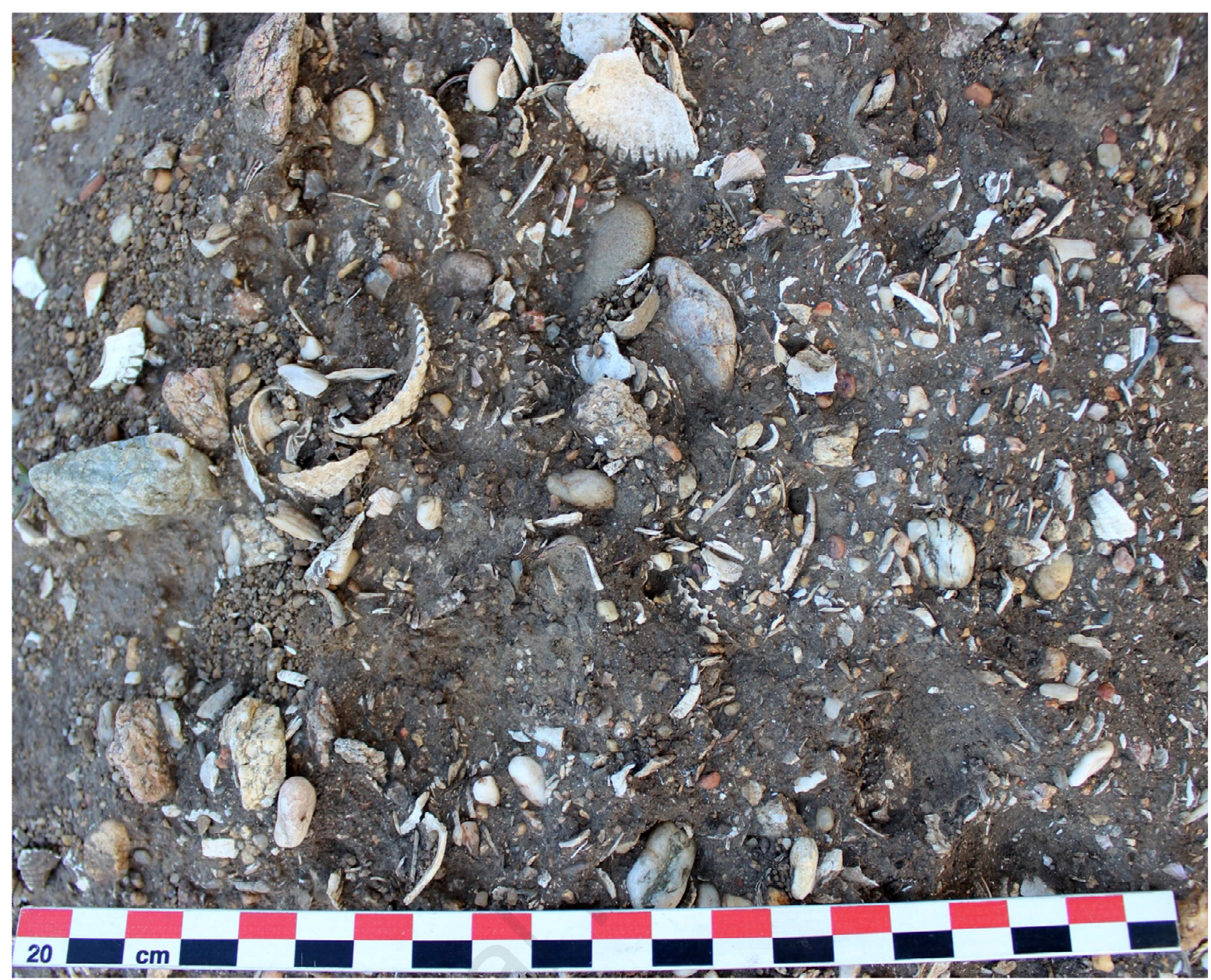

Fig. 5. Detail view of the archaeological level from Beg-er-Vil in Quiberon (Morbihan, France) (Photo: G. Marchand, CNRS).

The overall layout indicates the unequivocal plan of a circular dwelling structure with a diameter of $3.5 \mathrm{~m}$. In the middle of this circular structure, a pit with a diameter of $1.5 \mathrm{~m}$ and a depth of $0.5 \mathrm{~m}$, filled with burnt charcoal and bones, was delimited by intensely rolled slabs, sloped at $45^{\circ}$ and carefully arranged. Two metres to the northwest of this structure, another large combustion pit was surrounded by stakes, also circular-shaped but with a more altered outline. Several functional interpretations are possible for these two structures around large pit fireplaces (wigwam, sweat lodge, drying device for animal fillets, wind screen...). The sandy area also comprises pit fireplaces and small flat hearths with a paved area. Lithic objects ranging from flint chips to tools abandoned after use are widely distributed over the entire surface of the excavation, with a higher concentration in the shell deposit. At this stage of the investigation, it is striking that the structures indicate a clear spatial organization of the habitat, whereas the spatial distribution of the lithic elements evokes a continuous layer (Marchand et al., 2018). The high rate of burned lithic pieces (mainly from local flint pebbles) 
and the abundance of debitage remains converge towards the interpretation of a perennial dwelling site, which is corroborated by dietary analyses and domestic structures.

\subsection{The impact of differential sampling methods and preservation conditions}

The different excavation methods used over the past two centuries on shell middens in northwestern France clearly yield highly variable degrees of information depending on investment related to the sieving and sorting of sieved sediments in the field and in the laboratory. For the oldest excavations of the two shell middens with necropolises, we note that it is difficult to go back to already excavated areas. Several tests have been made using excavation photographs but they show the limits of stratigraphic interpretations (Boulestin, 2016). To clarify these questions, all the archaeological remains at Beg-er-Vil were collected per quarter of a square metre with full screening of the sediments with 4 and $2 \mathrm{~mm}$ meshes, first of all with sea water, followed by rinsing with fresh water. Only part of the sediments could be sieved at $0.5 \mathrm{~mm}$ in the laboratory with fresh water. All the remains retained in the $4 \mathrm{~mm}$ mesh were sorted. For the $2 \mathrm{~mm}$ mesh, the same protocol was applied, except for the shells. For the latter, we initially extracted all shell parts used for calculating the MNI (Minimum Number of Individuals) and we then carried out sampling to calculate the NISP (Number of Individual Specimens). For the NISP, we counted all the shell fragments in a fraction of the sample. The long-term aim of this sieving is to investigate the spatial distribution and composition of the various artefacts at the site in relation to the identified structures and taphonomic biases. All the remains of animals and plants exploited by this Mesolithic population were considered as artefacts. As of November 2018, the pH of 1,772 samples has already been measured, while 310 samples have been analysed by X-ray fluorescence.

Consequently, the sampling protocol applied at Beg-er-Vil paves the way for a better knowledge of the biodiversity of coastal areas in the Mesolithic period, on the north-western coast of France, through the filter of human activities. This protocol, combining sieving and the exhaustive sorting of sediment samples, has already proved useful in other Mesolithic shell middens at the European scale (for example: Straus and Clark, 1986; Connock et al., 1993, García-Escárzaga et al., 2017; Finlay et al. 2019). It presents a more realistic representation of the proportions of exploited species by circumventing the underestimation of the most friable or smallest species. Some of these small species may reflect the contribution of other marine products, such as algae for example (Lubell, 1984; Connock et al., 1993; 
Mougne et al. 2014). The exhaustive analysis of several dozen square metres of excavation will also enable us to characterize the heterogeneity of the composition of the dump. Similarly, these operations at Beg-er-Vil allow us to address a major question for the evolution of this type of site. It is generally accepted that some of these accumulations were probably dissolved as a result of the acidity of the substrate, but the study of the fragmentation of the specialized archaeological remains will undoubtedly verify what we have already described for the Beg-an-Dorchenn shell midden (Dupont, 2006; Dupont et al., 2010); namely, that the shell midden is a system in a fragile state of equilibrium, due to high acidity levels, and that this equilibrium generally deteriorates throughout time, leading to the dissolution of the shells composing the structure. The consequences of these results are crucial, as they show that shell middens are endangered sites which require archaeological monitoring. Moreover, this 'self-digestion' of the shell midden undoubtedly underlies the differential representation of some remains, such as those of animal origin. Our focus on the 'crumbs' of the midden will undoubtedly contribute to explaining some of the gaps in the spatial distribution of shell middens.

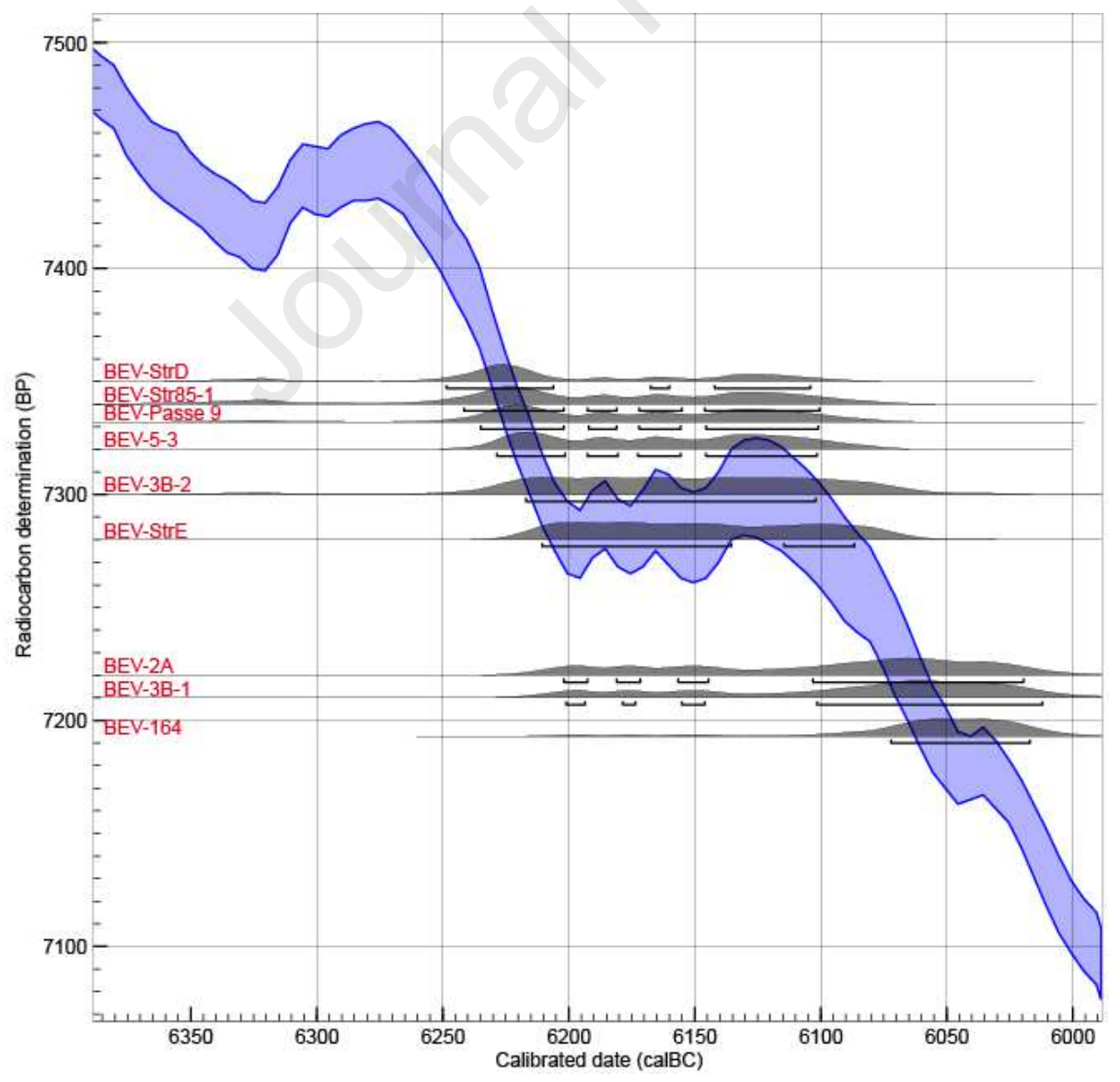


Fig. 6. Position of Beg-er-Vil (Quiberon, Morbihan) calibrated dates on the calibration curve obtained on Oxcal 4.3.2 (Bronk Ramsey, 2017), IntCal13 atmospheric curve (Reimer et al., 2013). The date codes are in Table 4 (Oxcal, modified by G. Marchand).

\begin{tabular}{|c|c|c|c|c|c|c|c|c|}
\hline $\begin{array}{c}\text { Stratigraphic } \\
\text { Unit }\end{array}$ & Reference & Code & BP & $+/-$ & $\mathbf{S}^{13} \mathbf{C}$ & $\begin{array}{c}\text { Dated } \\
\text { material }\end{array}$ & $\begin{array}{c}\text { Lower } \\
\mathbf{( 6 8 . 2 \% )})\end{array}$ & $\begin{array}{c}\text { Top } \\
\mathbf{( 6 8 . 2 \% )}\end{array}$ \\
\hline $\begin{array}{c}\text { Couche 3B - } \\
\text { Passes 8-9- } \\
\text { Carré AF20 - } \\
\text { Fosse 1 }\end{array}$ & Beta-259108 & BEV-Str85-1 & 7340 & 40 & -25.1 & $\begin{array}{c}\text { Charcoal } \\
\text { (twig) }\end{array}$ & 6242 & 6101 \\
\hline $\begin{array}{c}\text { US 32-BD36 } \\
\text { C (Structure } \\
\text { D) }\end{array}$ & Beta-421803 & BEV-StrD & 7350 & 30 & -25.0 & $\begin{array}{c}\text { Charcoal } \\
\text { (twig) }\end{array}$ & 6249 & 6105 \\
\hline $\begin{array}{c}\text { US 5.3 BG36 } \\
\text { C }\end{array}$ & Beta-421805 & BEV-5-3 & 7320 & 30 & -23.8 & $\begin{array}{c}\text { Charcoal } \\
\text { (twig) }\end{array}$ & 6229 & 6102 \\
\hline $\begin{array}{c}\text { Couche 3B- } \\
\text { Passe 6- } \\
\text { Carré AH21 - } \\
\text { cadran B }\end{array}$ & Beta-253154 & BEV-3B-2 & 7300 & 50 & -24.9 & $\begin{array}{c}\text { Charcoal } \\
\text { (twig) }\end{array}$ & 6218 & 6103 \\
\hline $\begin{array}{c}\text { AG 20-197 } \\
\text { Passe 9 }\end{array}$ & OxA-25915 & BEV-Passe 9 & 7332 & 35 & -22.08 & $\begin{array}{c}\text { Bone (roe } \\
\text { deer) }\end{array}$ & 6236 & 6102 \\
\hline $\begin{array}{c}\text { US 42 BC37 } \\
\text { A (Structure } \\
\text { E) }\end{array}$ & Beta-421804 & BEV-StrE & 7280 & 30 & -26.0 & $\begin{array}{c}\text { Charcoal } \\
\text { (twig) }\end{array}$ & 6211 & 6087 \\
\hline $\begin{array}{c}\text { Couche 2A - } \\
\text { AH20 }\end{array}$ & Beta-274301 & BEV-2A & 7220 & 50 & -27.1 & Fruit & 6203 & 6020 \\
\hline $\begin{array}{c}\text { Couche 3B - } \\
\text { Passe 6- } \\
\text { Carré AH21 }\end{array}$ & Beta-253153 & BEV-3B-1 & 7210 & 50 & -27.2 & Fruit & 6202 & 6013 \\
\hline $\begin{array}{c}\text { AG 23-164 } \\
\text { Passe 6 }\end{array}$ & OxA-25916 & BEV-164 & 7193 & 36 & -21.61 & $\begin{array}{c}\text { Bone (roe } \\
\text { deer) }\end{array}$ & 6073 & 6018 \\
\hline
\end{tabular}

Table 4. Radiocarbon dates of stratigraphic units of Beg-er-Vil obtained from charcoals (twigs) or deer bones. Calibration is performed at 1 sigma (68.2\%) on the Oxcal 4.3 software (IntCal13 curve).

\section{First results: new understanding of the Mesolithic maritime economy in Western}

\section{France}

\subsection{Spatial organisation}

Our knowledge of the diversity of Mesolithic activities has increased in recent years thanks to combined efforts and advances in fieldwork and post-excavation methods. These shell midden sites are places where Mesolithic people lived, where they cooked, where they buried their relatives, where they discarded waste from many daily activities, as well as being places of 


\section{Journal Pre-proof}

rituals (Fig. 7). In the current state of analysis, it is clear that food and flint knapping waste were discharged into the midden, but, on the other hand, no lithic knapping areas or zones where tools were made have yet been identified. Lithic remains are widely dispersed over the entire excavation area, whereas the plan of the dwelling is much clearer. This may be partly due to the effects of a remobilization of the remains during human movements, but also to the effects of climatic conditions. Hollows in the soil (pit hearths) and other domestic amenities are not restricted to the shell deposit area alone, but extend around it. Men and women would have radiated around the occupation to obtain food and raw materials. It is difficult to identify activity areas, but paleoenvironmental reconstructions have shown that all the resources used on these sites were probably accessible within a radius of $5 \mathrm{~km}$ (Dupont et al., 2009).

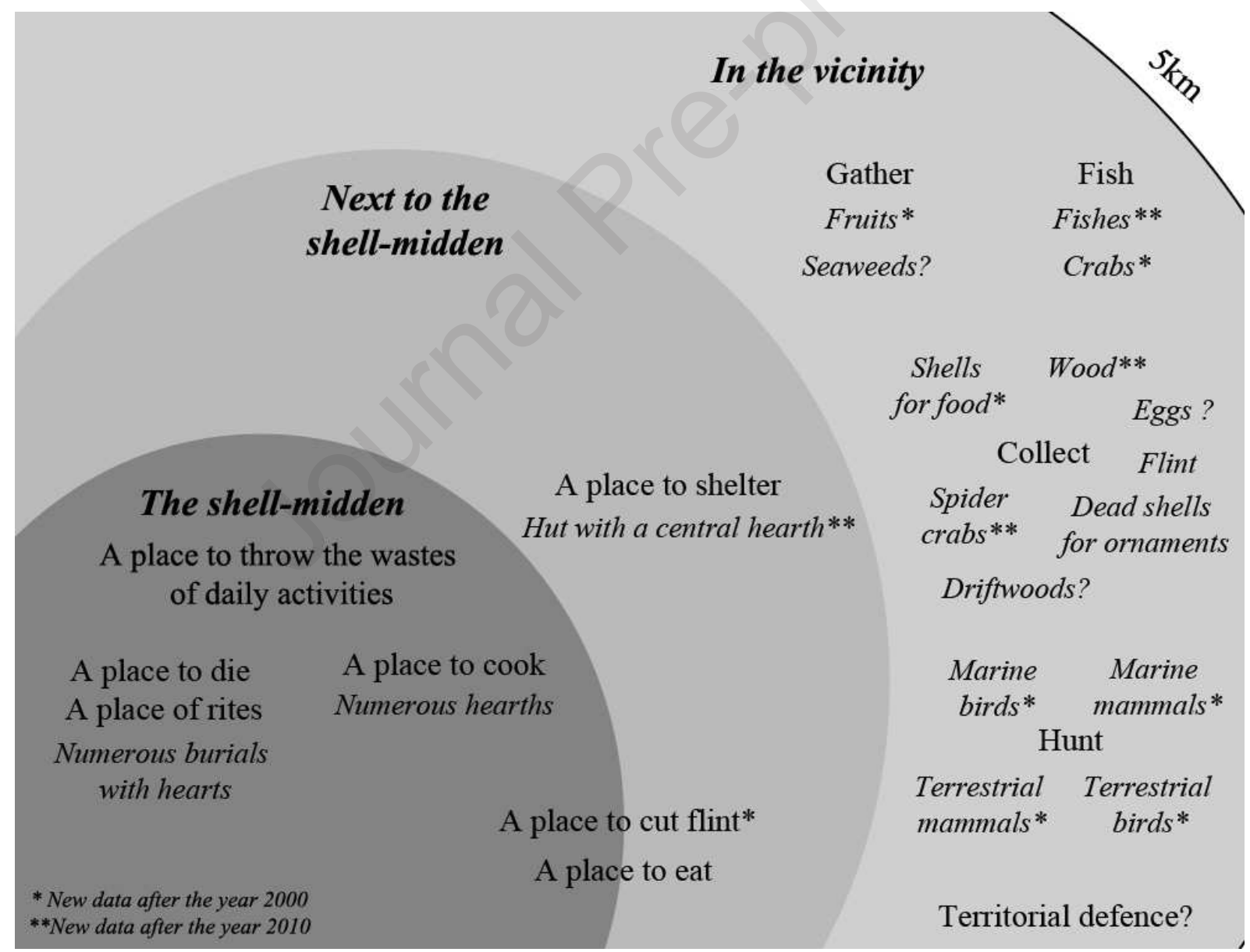

Fig. 7. Multiple activities observed after archaeological studies on French Late Mesolithic shell middens (CAD C. Dupont CNRS)

\subsection{Palaeodietary reconstruction}


As seen above, the consumption of seafood was recognized by archaeologists since the earliest excavations, but was only sketchily described and largely undervalued in comparison with hunting resources. Stable carbon and nitrogen analyses helped to reactivate the contribution of marine resources to the diet (Schulting and Richards, 2001; Schulting, 2005). The results from the combination of sieving/sorting portray populations involved in a variety of activities, for whom hunting was not the sole or the main activity (Fig. 7). While the presence of terrestrial and marine animals had been detected by previous excavations, recent sieving associated with the sorting process has provided information on a greater diversity of exploited species, including birds, mammals, but also fish, crabs and marine molluscs. These preys reveal evidence of different fishing, hunting and even collecting strategies. The identification of fish remains points to fishing activities from the coastline, or even the use of stone-built fisheries to trap fish at low tide. Such stone fish weirs are known along the French coasts on exposed and rocky shores and woody ones are also observed on sheltered areas (Billard et al., 2019) and many of these remain undated (Billard et al., 2019). Their presentday tidal level with reference to the Holocene sea-level curve of the region can give us information of their period of use (Daire and Langouët, 2011). According to their heights relative to current sea level, it is possible that some could be attributed to the Mesolithic or Neolithic period in Brittany (Billard and Bernard, 2016; Billard et al., 2019). A geophysical prospection (sonar surveys, sediment penetrator) to investigate potential evidence for a fish weir was attempted in front of Beg-er-Vil, was unsuccessful.

Among the represented species, some are indicators of the human occupation of these sites on an annual basis. The rate of growth studied on European carpet shells gives us access to the gathering season of this species (depending here on the location of samples), although marine molluscs can be accessible all year round (Dupont, 2006). Fish are present all year round in the region, but they swim closer to the coast during autumn which facilitates their capture. Mammals and birds also point to a wide diversity of exploited environments (Fig. 8), and probably also reflect varied modes of capture. Some of the bird species are only present on the coast during nesting periods (Fig. 8). They are particularly vulnerable at such times and may have been hunted with bows and arrows but also possibly trapped by nets. We can thus envisage that Mesolithic people had access to bird eggs, though no evidence for egg shell has been identified as yet, perhaps on account of their fragility and porosity. 


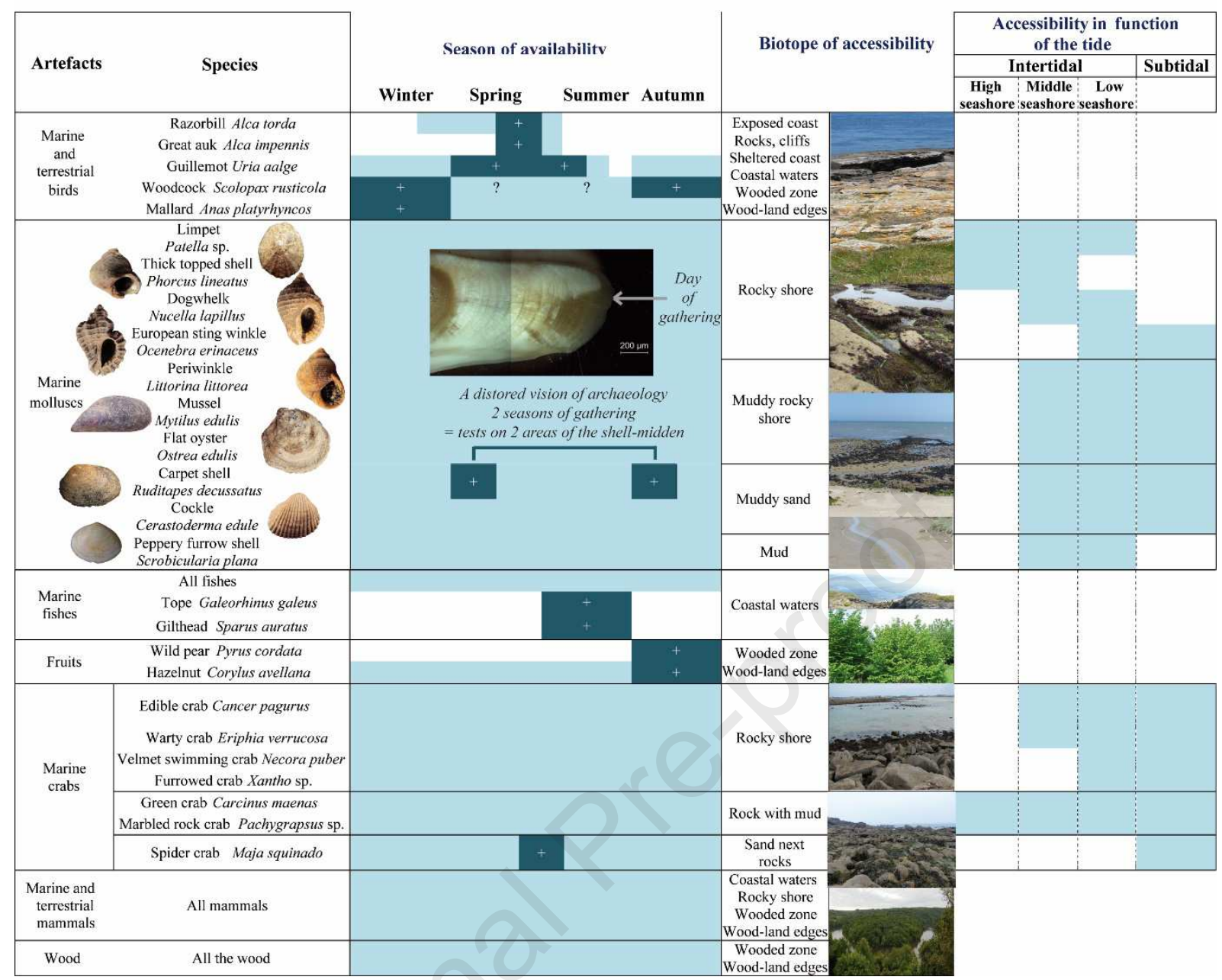

Fig. 8. Seasonal availability of exploited resources and their biotopes at Beg-er-Vil (in dark blue: the period when the resource is most accessible, in light blue: when the resource is commonly accessible; in white: when the resource is not accessible updated after Dupont et al., 2009, CAD C. Dupont CNRS)

Methodological developments have also had a major impact on our vision of crab harvesting along the French Atlantic façade during the Mesolithic, as in other countries (for example: Milner, 2009; Pickard and Bonsall, 2009; Iriate et al. 2010; Dupont, 2011; Gutiérrez-Zugasti et al., 2016). From the earliest excavations onwards, the main described crab species was the large crab Cancer pagurus Linnaeus 1758 (Dupont and Gruet, 2005; Gruet, 2002). Size reconstruction based on fragments of pincers showed that the largest specimens of each species were selected. This view seems to have been partly biased by the techniques used to collect these elements during excavation, i.e., visual collecting in the first half of the twentieth century and sieving with a $5 \mathrm{~mm}$ mesh in the 1980s. The first tests carried out on the study of the 4- and 2-mm mesh crab remains at Beg-er-Vil show that a wide spectrum of species and individuals accessible in the vicinity of the site were exploited. The methods used by archaeologists to collect crab remains in the field have thus transformed our vision of 
Mesolithic behaviour from a selective to a more opportunistic behaviour. Sieving has also led to the identification of the spider crab Maja squinado (Herbst, 1788), which previously went unnoticed by archaeologists' sieves. This represents another milestone concerning the presence of these human populations on the north-western coasts of France (Fig. 8). This species comes closer to our coasts in the spring when marine waters warm up. Some individuals can be washed ashore during this period and the small number of identified fragments of this species at Beg-er-Vil may correspond to this seasonal and opportunistic capture. Likewise, the correlation between the accessibility and exploitation of shells demonstrates that these Mesolithic groups were familiar with the diversity of the accessible intertidal environments and undoubtedly of tidal cycles. All the species collected alive are accessible on dry land at low tide. This strategy limits the risks inherent to fishing and gathering further from the shore by apnoea. The indices of activities by entering the water up to the torso are also lacking. We can for example, quote the absence of the abalone Haliotis tuberculate currently fished in Brittany by this way. It may also signify that populations had enough available food in this area on a daily basis on the intertidal zone. But shells also give us access to an activity rarely described for the last hunter-gatherers on the French Atlantic coast, namely collecting products washed up on the beach (Dupont, 2019). Although this activity is still difficult to prove for some exploited natural resources, such as wood and some fish species, it is assumed for flint and clearly demonstrated for shells subsequently used as ornaments (Fig. 7). These data from sites where marine molluscs were used both as food and raw materials for ornaments renew our vision of these populations in Western France. The search for food was not their sole objective. The description of the shells used to make ornaments shows that shell collecting was undoubtedly well differentiated in the daily life of these populations (Dupont, 2019) as this activity is not dependent on the tide, unlike the collection of shells from rocks, sand or mud. The discovery of thousands of these ornaments associated with the Téviec and Hoedic burials reflects the importance of these objects and undoubtedly indirectly of the quest for these raw materials for maritime populations. This focus on ocean-derived materials for adornment is not due to chance and confirms the strong links of these populations with the marine environment, as is already visible in their diet. In the current state of research, it appears that this beach-combing activity, which consists of surveying the coastline to see what the sea has washed up, undoubtedly also participated in the collection of flint nodules. The evidence we now have, of the presence of this population on an annual basis, even raises the question of residential stabilization, although this cannot yet be proven with certainty. 


\section{6- Conclusion and discussion}

As stated above, revising French Mesolithic shell middens through new excavations is not unique at the Atlantic European scale. Other similar operations involve renewed fieldwork or reanalyses of archaeological material (Bicho et al., 2015; Fernandez-Lopez de Pablo and Gabriel, 2015; García-Escárzaga et al., 2017). For decades, the human bones from these shell middens, excavated in the first half of the twentieth century, overshadowed the scientific interest of the shell layers themselves. This former lack of interest contrasts with the huge potential of these shells recently revealed by the development of sieving sometimes associated with exhaustive sorting (Russell et al., 1995).

Our perception of the last hunter-gatherers on the French Atlantic coast underwent a major paradigm shift in the 1980s and was subsequently enriched by many new study methods and techniques at the end of the 1990s. In recent years, a genuine revolution in techniques for recording remains and structures has taken place. The excavations carried out for seven years at Beg-er-Vil have had diverse consequences on our perception of other Mesolithic coastal sites in Atlantic France. They have, in particular:

- changed perspectives by ceasing to consider shell middens as a distinctive type of site with its own uniform characteristics, but rather as settlements, connected to their natural environment, with varied deposits and features in which layers of shells also occur intermittently,

- better quantified and analysed paleo-environmental and paleo-economic data, including a better understanding of post-depositional chemical and erosive processes,

- enhanced our knowledge of the chronology of shell middens, not only by radiocarbon dating, but also by a systematic geoarchaeological approach to sedimentary deposits,

- increased the evidence for artefacts that leave small remains and thus highlighted the diversity of species and related activities.

As a result, we are able to determine that Mesolithic hunter-gatherers from the French Atlantic coast were fisher-hunter-gatherers taking advantage of the diversity offered by coastal environments. At the interface between ocean and land, they made use of daily tides and seasonal cycles to extract many species that remain invisible without a detailed 
knowledge of the nearby environment. Thus, they were able to dig out sand and mud to unearth species of shellfish, lift rocks to flush out crabs, wait for the nesting periods of some sea birds to catch and eat them, and take advantage of the fruit-ripening season. They also spent time surveying the beach and benefitted from what the sea washed up. Such strategies, clearly separated from the procurement of living prey, have been described in other parts of the word such as South Africa for example (Parkington et al., 2014). The diversity of marine invertebrates observed in Beg-er-Vil does not seem to represent an occupation corresponding to just a few days. It is even legitimate to raise the possibility of the inter-generational transmission of collecting spots, given that this diversity encompasses just about everything that could be eaten. This pressure on accessible resources does not seem to have involved human risk-taking to obtain food. Current data show no physical evidence of humans extending past the coastal zone for food. No shellfish species requiring total immersion in water were collected. Similarly, fish could have been caught from the shoreline without a boat and the hypothesis of the use of fish weirs remains open.

More than fifteen archaeological disciplines have been involved in the study of the Beg-er-Vil shell midden. Unprecedented methodological developments for this region have led to the discovery of hitherto invisible archaeological remains. The comparison of data according to the diverse excavation techniques employed highlights the necessity for caution in archaeological interpretations. However, sieving shell middens also has its limits: namely the conservation of huge volumes of shells. Although, sorting is the first step in the process because it compresses these volumes, the next step is convincing the competent authorities to keep these animal skeletons. These remains are our heritage and bear witness to past biodiversity and human activities. It remains very difficult to anticipate exactly what our trowels should save, in systems where shell mass dissolves over time and the accuracy of analytical techniques changes on a daily basis.

\section{5- References}

Amkreutz, L., 2013. Persistent Traditions. A long-term perspective on communities in the process of Neolithisation in the Lower Rhine Area (5500-2500 cal BC). Sidestone Press Dissertations, Leiden. 
Andersen, S. H., 2000. Køkkenmøddinger (shell middens) in Denmark: A survey. Proceedings of the Prehistoric Society. 66, 361-384. https//doi.org/10.1017/S0079497X00001857

Andersen, S. H., 2013. Tybrind Vig. Submerged Mesolithic Settlements in Denmark. Jutland Archaeological Society Publications. 77, Jutland Archaeological Society, Højbjerg.

Andersen, SH., Johansen, E., 1986. Ertebølle revisited. Journal of Danish Archaeology. 5, 3161. https://doi.org/10.1080/0108464X.1986.10589957.

Arias, P., Diniz, M., Cubas, M., Duarte, C., Iriarte, E., Salzmann, C., Teichner, F., Teira, L., 2017. Looking for the traces of the last hunter-gatherers: Geophysical survey in the Mesolithic shell middens of the Sado valley (southern Portugal). Quaternary International. 435, 61-70. https://doi.org/10.1016/j.quaint.2016.02.016.

Arnaud, J. M., 1989. The mesolithic communities of the Sado valley, Portugal, in their ecological setting, in: Bonsall C. (ed), The Mesolithic in Europe. Papers presented at the third International Symposium, John Donald, Edinburgh, pp. 614-631.

Bailey, G. N., Hardy, K., Camara A. (Eds.), 2013. Shell Energy: Mollusc Shells as Coastal Resources. Oxbow Books, Oxford

Bénard Le Pontois, Cdt., 1929. Le Finistère Préhistorique. Publications de l'Institut International d'Anthropologie, $n^{\circ}$ 3, Librairie Emile Noury, Paris.

Bicho, N., Detry, C., Price, T. D., Cunha, E. (Eds.), 2015. Muge 150th, The 150th Anniversary of the Discovery of Mesolithic Shellmiddens. Vol. 1/2, Cambridge Scholars Publishing, Newcastle.

Bicho, N., Umbelino, C., Detry, C., Telmo Pereira, T., 2010. The Emergence of Muge Mesolithic Shell Middens in Central Portugal and the $8200 \mathrm{cal}$ yr BP Cold Event, Journal of Island and Coastal Archaeology. 5, 86-104. https://doi.org/10.1080/15564891003638184

Billard, C., Bernard, V., 2016. Les barrages à poissons au Mésolithique. Une économie de prédation ou de production ? in Dupont, C., Marchand, G. (Eds.), Archaeology of maritime hunter-gatherers. From settlement function to the organization of the coastal zone. Actes de la séance de la Société préhistorique française de Rennes, 10-11 avril 2014. Société $\begin{array}{llll}\text { préhistorique } & \text { française, } & \text { Paris, } & \text { 113-125. }\end{array}$ http://www.prehistoire.org/offres/file_inline_src/515/515_P_41148_58512e3e298f5_7.pdf

Billard, C., Daire, M.Y., Martin C., Billaud, Y., Bizien-Jaglin, C., Chancerel, A., Cliquet, D., Fourment, N., Gandois, H., Huet, B., Laforge, M., Langouët, L., Laporte, L., Large, J.-M., Leroy, F., López-Romero, E., Maurel, L., Monnier, J.-M., Régaldo, P., Ropars, A., 
Stéphan, P., Vallin, L., 2019. France: Submerged Prehistory on Atlantic and Mediterranean Coasts, in: Bailey, G., Galanidou, N., Peeters, H., Jöns, H., Mennenga, M. (Eds.), The Archaeology of Europe's Drowned Landscapes, Springer, New-York, Coastal Research Library 35, pp. 249-280.

Binford, L. R., 2001. Constructing Frames of reference. An analytical method for archaeological theory building using ethnographic and environmental data sets. University of California Press, Berkeley.

Boulestin, B., 2016. Les sépultures mésolithiques de Téviec et Hoedic : révisions bioarchéologiques. Archaeopress, Oxford.

Breuil, H., Zbyszewski, G., 1947. Révision des industries mésolithiques de Muge et de Magos, Communicaçoes dos serviços geológicos de Portugal, 28, 149-196.

Bronk Ramsey, C., 2017. Methods for Summarizing Radiocarbon Datasets. Radiocarbon, 592, 1809-1833.

Calvo Gómez, J., 2018. Las flechas tranchantes del segundo Mesolítico en Bretaña: interpretación funcional a través de la experimentación, in: Agudo Pérez, L., Duarte, C., Garcia Escarzaga, A., Geilling, J. M., Higuero Pliego, A., Nunez de la Fuente, S., Rodriguez Santos, F.J., Suarez Revilla, R. (Eds.), IX Jornadas de Jóvenes en Investigación Arqueológica, Santander 8-11 de junio 2016, Universidad de Cantabria, Santander, pp. 8190.

Clark, J. G. D., 1952. Prehistoric Europe: The Economic Basis. Philosophical Library, New York.

Connock, K.D., Finlayson, B., Mills, C.M., 1993. Excavation of a shell midden at Carding Mill Bay, near Oban, Scotland. Glasgow Archaeological Journal. 17, 25-38. https://doi.org/10.3366/gas.1991.17.17.25.

Daire, M.-Y., Langouët, L. 2011. Dater les anciennes pêcheries par les niveaux marins: approches méthodologiques et perspectives géo-archéologiques: le Bas-Léon, nord Finistère, Bretagne. Norois, 220, 3-25. https://doi.org/10.4000/norois.3680.

David, E., 2017. The Bone Pins from Téviec (Morbihan, France) Illuminate Mesolithic Social Organization, in: Grünberg, J.M., Gramsch, B., Larsson, L., Orschiedt, J., Meller, H. (Eds.), Mesolithic Burials - Rites, Symbols and Social Organisation of Early Postglacial Communities. Tagungen Des Landesmuseums Für Vorgeschichte Halle, Halle, pp. 609628.

Deschler-Erb, S., 2019, Pride and Prejudice? On the Relationship Between Archaeology and Biosciences, in: Brather-Walter S. (Ed.), Archaeology, History and Biosciences. 
Ergänzungsbände zum Reallexikon der Germanischen Altertumskunde, Band 107. Berlin pp. 23-32.

Djindjian, F., 2016. The Revolution of the Sixties in Prehistory and Protohistory, in: Delley, G., Díaz-Andreu, M., Djindjian, F., Fernández, V. M., Guidi, A., Kaese, M.-A. (Eds.), History of Archaeology: International Perspectives. Proceedings of the XVII UISPP World Congress (1-7 September 2014, Burgos, Spain), Archaeopress, Oxford, pp. 125-144.

Du Châtellier, P., 1881. Exploration des tumulus de Run-Aour et de la Torche en Plomeur (Finistère) et du Kjökkenmödding de la Torche. Mémoires de la Société d'Émulation de Côtes-du-Nord. 19, 175-182.

Dupont, C., 2003. La malacofaune de sites mésolithiques et néolithiques de la façade atlantique de la France : Contribution à l'économie et à l'identité culturelle des groupes concernés. PhD, Université de Paris I-Panthéon-Sorbonne.

Dupont, C., 2006. La malacofaune de sites mésolithiques et néolithiques de la façade atlantique de la France : Contribution à l'économie et à l'identité culturelle des groupes concernés. British Archaeological Reports International Series 1571. Archeopress, Oxford.

Dupont, C., 2011. Les invertébrés marins du « concheiro » de Toledo (Lourinhã, Portugal), in: Araújo, A.C. (Ed.), O concheiro de Toledo no contexto do Mesolítico inicial di litoral da Estremadura. Trabalhos de Arqueologia 51. Igespar, Lisboa, pp. 185-227.

Dupont, C., 2019. Archaeological evidence for collecting empty shells along the French Atlantic coast: A major activity for coastal populations. Journal of Ethnobiology. 39(2), 223-239. https://doi.org/10.2993/0278-0771-39.2.223.

Dupont, C., Gruet, Y., 2005. Malacofaune et crustacés marins des amas coquilliers mésolithiques de Beg-an-Dorchenn (Plomeur, Finistère) et de Beg-er-Vil (Quiberon, Morbihan), in: Marchand, G., Tresset, A. (Eds.), Unité et diversité des processus de néolithisation sur la façade atlantique de l'Europe (6e-4e millénaires avant J.-C.), Table ronde de Nantes 26-27 avril 2002, Mémoire de la Société Préhistorique Française 36, pp. $139-161$

Dupont, C., Marchand, G., 2008. Coastal exploitation in the Mesolithic of western France: la Pointe Saint-Gildas (Préfailles). Environmental Archaeology. 13/2, 143-152. https://doi.org/10.1179/174963108X343263.

Dupont, C., Marchand, G., Carrion, Y., Desse-Berset, N., Gaudin, L., Gruet, Y., Marguerie, D., Oberlin, C., 2010. Beg-an-Dorchenn : une fenêtre ouverte sur l'exploitation du littoral par les peuples mésolithiques du sixième millénaire dans l'ouest de la France. Bulletin de la Société Préhistorique Française. 107-2, 227-290. https://doi.org/10.3406/bspf.2010.13929. 
Dupont, C., Tresset, A., Desse-Berset, N., Gruet, Y., Marchand, G., Schulting, R., 2009. Harvesting the seashores in the Late Mesolithic of north-western Europe. A view from Brittany? Journal of World Prehistory. 22/2, 93-111. https://doi.org/10.1007/s10963-0099017-3.

Dupont, C., Tresset, A., Schulting, R., 2007. Prehistoric shell middens in France: investigations new and old, in: Milner, N., Craig, O.E., Bailey, G.N. (Eds.), Shell-Middens in Atlantic Europe. Oxbow books, Oxford, pp. 123-135

Erlandson, J.M., 1988. The Role of Shellfish in Prehistoric Economies: A Protein Perspective. American Antiquity, 53-1, 102-109.

Fernandez-Lopez de Pablo, J., Gabriel, S., 2015. El Collado shell midden and the exploitation patterns of littoral resources during the Mesolithic in the Eastern Iberian Peninsula. Quaternary International. 407, 106-117. https://doi.org/10.1016/j.quaint.2015.11.100.

Fischer, A., (Ed.), 1995. Man and sea in Mesolithic. Coastal settlement above and below present sea level. Proceedings of the International Symposium Kalundborg, Denmark 1993. Oxford Monograph 53, Oxbow.

Finlay, N., Cerón-Carrasco, R., Housley, R., Huggett, J., Jardine, W., Ramsay, S., Wright, P., 2019. Calling Time on Oronsay: Revising Settlement Models Around the MesolithicNeolithic Transition in Western Scotland, New Evidence from Port Lobh, Colonsay. Proceedings of the Prehistoric Society. 85, 83-114. https://doi:10.1017/ppr.2019.2.

Gaillard, F., 1885. Une exploration archéologique à l'île de Téviec. Bulletins et Mémoires de la Société d'Anthropologie de Paris. 8, 406-415. https://doi.org/10.3406/bmsap.1885.6389.

García-Escárzaga, A., Gutiérrez-Zugasti, I., González-Morales, M.R., Cobo-García, A., 2017. Shells and Humans: Molluscs and Other Coastal Resources from the Earliest Human Occupations at the Mesolithic Shell Midden of El Mazo (Asturias, Northern Spain). Papers from the Institute of Archaeology. 27(1), 1-17, https://doi.org/10.5334/pia-481.

González Morales, M., Clark, G.A. (Eds.), 2004. The Mesolithic of the Atlantic Façade: proceedings of the Santander Symposium. Anthropological Research Papers 55, Arizona State University.

Grieve, D., 1874. Notes on the shell-level near Inveravon, Linlithgow. Proceedings of the Society of Antiquaries of Scotland. 9, 45-52.

Gruet, Y., 2002. Reconnaissance de quelques espèces communes de crustacés (crabes et balanes) : application au site mésolithique de Beg-er-Vil (Morbihan, France). Revue d'Archéométrie. 26, 125-139. https://doi.org/10.3406/arsci.2002.1028. 
Guéret, G., Gassin, B., Jacquier, J., Marchand, G., 2014. Traces of plant crafting in the Mesolithic shell midden of Beg-an-Dorchenn (Plomeur, France). Mesolithic Miscellany. 22-3, 5-15.

Gutiérrez-Zugasti, I., Andersen, S.H., Araujo, A.C., Dupont, C., Milner, N., Monge-Soares, A.M., 2011. Shell middens in Atlantic Europe: state of art and new perspectives for future $\begin{array}{llll}\text { research. } & \text { Quaternary } & \text { 230-85.1-2, }\end{array}$ https://doi.org/10.1016/j.quaint.2011.02.031.

Gutiérrez-Zugasti, I., Cuenca Solana, D., Rasines Del Río, P., Muñoz Fernández, E., Santamaría, S., Morlote Expósito, J.M., 2013. The role of shellfish in hunter-gatherer societies during the early Upper Palaeolithic: a view from El Cuco rockshelter, Northern Spain. Journal of Anthropological Archaeology 32, 242-256. http://dx.doi.org/10.1016/j.jaa.2013.03.001

Gutiérrez-Zugasti, I., González-Morales, M.R., Cuenca-Solana, D., Fuertes, N., GarcíaMoreno, A., Ortiz-Menéndez, J.E., Rissetto, J., Torres, T.D., 2014. La ocupación de la costa durante el Mesolítico en el Oriente de Asturias: primeros resultados de las excavaciones en la cueva de El Mazo (Andrín, Llanes). Archaeofauna 23, 25-38.

Gutiérrez-Zugasti, I., Tong, E., Garcia-Escarzaga, A., Cuenca-Solana D., Bailey, G.N., Gonzalez-Morales, G.R., 2016. Collection and consumption of echinoderms and crustaceans at the Mesolithic shell midden site of El Mazo (northern Iberia): Opportunistic behaviour or social strategy? Quaternary International. 407, 118-130. https://doi.org/10.1016/j.quaint.2015.11.149.

Iriate, M.J., Arrizabalaga, A., Etxeberria, F., Herrasti, L., Álvarez-Fernández, E., 2010. Shell midden people in Northern Iberia. New data from the Mesolithic rock shelter of J3 (Basque country, Spain). Zephyrus. LXV, 117-127.

Kayser, O., 1985. A propos de la fin du Mésolithique en Bretagne : l'amas coquillier de Began-Dorchenn (Finistère). Note préliminaire. Travaux de l'Institut d'art préhistorique, Université de Toulouse-Le-Mirail, pp. 80-92.

Kayser, O., 1987. Beg-er-Vil : Quiberon (Morbihan), Campagne 1987, Sauvetage programmé $\mathrm{n}^{\circ} 1400$ site $\mathrm{n}^{\circ} 56186$ 007, Programme 24, SRA Bretagne, Rennes.

Kayser, O., 1992. Les industries lithiques de la fin du Mésolithique en Armorique, in: Leroux, C.T. (Ed.), Paysans et bâtisseurs, l'émergence du Néolithique atlantique et les origines du mégalithisme, Actes du XVIIème colloque interrégional sur le Néolithique, Vannes, 1990, Revue Archéologique de l'Ouest, Supplement 5, pp. 117-124. 
Kayser, O., Bernier, G., 1988. Nouveaux objets décorés du Mésolithique armoricain. Bulletin de la Société préhistorique française. 85-2, 45-47. https://doi.org/10.3406/bspf.1988.9319.

Kelly, R., 2007. The foraging spectrum. Diversity in Hunter-Gatherer lifeways. Percheron Press, New York.

Lacaille, A.D., 1954.The Stone Age in Scotland. University Press, Oxford.

Laporte, L., Dupont, C., 2019. Personal adornments and objects of ornamentation: two case studies from hunter-gatherer burials, in France (La Vergne) and Argentina (Arroyo Seco II). PaleoAnthropology. 156-176. https://doi.org/10.4207/PA.2019.ART129.

Lee, R.B., 1968. What hunters do for a living, or, How to make out on scarse resources ?, in: Lee, R.B., DeVore I. (Eds.), Man the Hunter. Adline, Chicago, pp. 30-48.

Lubell D., 1984. The Mesolithic-Neolithic transition as seen from Portugal: Preliminary report of 1984 Field Season. Mesolithic Miscellany. 5 (2), 7-11.

Lubbock, J., 1861. The Kjökkenmöddings: recent Geologico-Archæological Researches in Denmark. Natural History Review, 489-504.

Marchand, G., 1999. La néolithisation de l'ouest de la France : caractérisation des industries lithiques. British Archaeological Reports International Series 748, Archeopress, Oxford.

Marchand, G., 2014. Préhistoire atlantique. Fonctionnement et évolution des sociétés du Paléolithique au Néolithique. Éditions Errance, Arles.

Marchand, G., 2015. Living on the edge of the world: the Mesolithic communities of the atlantic coast in France and Portugal, in: Bicho, N., Detry, C., Price, T. D., Cunha, E. (Eds.), Muge 150th: The 150th Anniversary of the Discovery of Mesolithic Shellmiddens, Volume 1. Cambridge Scholars Publishing, Cambridge, pp. 273-285.

Marchand, G., 2017. Inventaire et interprétation des structures en creux des sites mésolithiques de France atlantique, in: Achard-Corompt, N., Ghesquière, E., Riquier, V. (Eds.), Digging in the Mesolithic, Actes de la séance de la Société préhistorique française, Châlons-en-Champagne, 29-30 mars 2016. Société préhistorique française, Paris, pp. 129146.htp://www.prehistoire.org/offres/file_inline_src/515/515_P_43494_5a1c2264d5864_1 3.pdf.

Marchand, G., Calvo Gómez, J., Cuenca Solana, D., Henin, A., Nukushina, D., 2019. Le macro-outillage en pierre du Mésolithique atlantique : un référentiel bien daté sur l'habitat littoral de Beg-er-Vil (Quiberon, Morbihan). Bulletin de la Société préhistorique française. $116,615-656$.

Marchand, G., Dupont, C., Delhon, C., Desse-Berset, N., Gruet, Y., Laforge, M., Le Bannier, J.-C., Netter, C., Nukushina, D., Onfray, M., Querré, G., Quesnel, L., Schulting, R., 
Stephan, P., Tresset, A., 2016. Retour à Beg-er-Vil, Nouvelles approches des chasseurscueilleurs maritimes de France Atlantique, in: Dupont, C., Marchand, G. (Eds.), Archaeology of maritime hunter-gatherers. From settlement function to the organization of the coastal zone. Actes de la séance de la Société préhistorique française de Rennes, 10-11 avril 2014. Société préhistorique française, Paris, pp. 283-319, http://www.prehistoire.org/offres/file_inline_src/515/515_P_41148_58512e3e298f5_14.pd $\mathrm{f}$

Marchand, G., Dupont, C., Laforge, M., Le Bannier, J.-C., Netter, C., Nukushina, D., Onfray, M., Querré, G., Quesnel, L., Stephan, P., 2018. Before the spatial analysis of Beg-er-Vil: a journey through the multiple archaeological dimensions of a Mesolithic dwelling in Atlantic France. Journal of Archaeological Science: Reports. http://dx.doi.org/10.1016/j.jasrep.2017.07.014, 18, 973-983.

Marchand, G., Dupont, C., Oberlin, C., Delque-Kolic, E., 2009. Entre « effet réservoir » et « effet de plateau » : la difficile datation du Mésolithique de Bretagne, in: Crombé, Ph., Van Strydonck, M., Sergant, J., Bats M., Boudin, M. (Eds.), Proceedings of the international congress "Chronology and Evolution in the Mesolithic of NW Europe", Brussels, May 30 June 1 2007. Cambridge Scholar Publishing, Cambridge, pp. 307-335.

Marchand, G., Schulting, R. 2019. Chronologie du second Mésolithique dans le Nord-Ouest de la France, in: Arbogast, R.M., Griselin, S., Jeunesse, C., Séara, F. (Eds.), Le second Mésolithique, des Alpes à l'Atlantique ( $\mathrm{VII}^{\circ}-\mathrm{V}^{\circ}$ millénaire). Table ronde internationale, Strasbourg, 3 et 4 novembre 2015, Mémoire d'Archéologie du Grand-Est, 3, pp. 109-125.

McCartan, S., Schulting, R., Warren, G., Woodman, P. (Eds.) 2009. Mesolithic Horizons, Papers presented at the 7th International Conference on the Mesolithic in Europe, Belfast 2005. Oxbow, Oxford.

Mellars, P., 1978. Excavation and Economic Analysis of Mesolithic Shell Middens on the Island of Oronsay, in: Mellars, P. (Ed.), The Early Postglacial Settlement of Northern Europe: An Ecological Perspective. Duckworth, London, pp. 371-96.

Mellars, P., 1987. Excavations on Oronsay: prehistoric human ecology on a small island. Edinburgh University Press, Edinburgh.

Milner, N., 2009. Consumption of crabs in the Mesolithic: side stepping the evidence?, in: Hardy, K., Wickham-Jones, C. (Eds.), Mesolithic and Later sites around the Inner Sound, Scotland: the Work of the Scotland's First Settlers Project 1998-2004. Scottish Archaeology Internet Publications, Edinburgh, 31, pp. 401-407. 
Milner, N., Woodman, P., 2007. Deconstructing the myths of Irish shell midden, in: Milner, N., Craig, O.E., Bailey, G.N. (Eds.), Shell Middens in Atlantic Europe. Oxbow Books, Oxford, pp. 101-110.

Moe Astrup, P., Skriver, C., Benjamin, J., Stankiewicz, F., Ward, I., McCarthy, J., Ross, P., Baggaley, P., Ulm, S., Bailey, G., 2019. Underwater Shell Middens: Excavation and Remote Sensing of a Submerged Mesolithic site at Hjarnø, Denmark, The Journal of Island and Coastal Archaeology. https://doi.org/10.1080/15564894.2019.1584135.

Mougne, C., Dupont, C., Baudry, A., Quesnel, L., Daire, M.-Y., 2014. Acquisition and management of the marine invertebrates resources on a pre-roman coastal settlement: Dossen-Rouz (Locquémeau-Trédez, Brittany, France), in: Szabó, K., Dupont, C., Dimitrijevic, V., Gastélum Gómez, L. G., Serrand, N. (Eds.), Archaeomalacology: Shells in the Archaeological Record. Proceedings of the 11th ICAZ International Conference. Paris - Archaeomalacology Working group, 23-28 August 2010, France, BAR International Series 2666. Archeopress, Oxford, pp. 203-216.

Newell, R. R., Kielman, D., Constandse-Westermann, T.S., Van der Sanden, W.A.B., Van Gijn, A., 1990. An Inquiry into the Ethnic Resolution of Mesolithic Regional Groups. The Study of Their Decorative Ornaments in Time and Space. Brill, New York.

Oliveira, F.P., 1888-1889. Nouvelles fouilles faites dans les Kioekkenmoeddings de la vallée du Tage. Comunicações da Comissão dos Trabalhos Geológicos de Portugal. 2-1, 57-81.

O’Sullivan A., Breen C., 2011 - Maritime Ireland an archaeology of coastal communities. History Press, Stroud, Gloucestershire.

Parkington, J., J. W. Fisher, C. Poggenpoel, and K. Kyriacou. 2014. Strandlooping as a Resource Gathering Strategy in the Cape, South African Holocene Later Stone Age. Journal of Island and Coastal Archaeology. 9, 219-237. https://doi.org/10.1080/15564894.2014.881936

Péquart, M., Péquart, S.-J., 1928. Un gisement mésolithique en Bretagne. L’Anthropologie. $38,479-493$.

Péquart, M., Péquart, S.-J., 1929. La nécropole mésolithique de Téviec. (Morbihan. Nouvelles découvertes). L'Anthropologie. 39, 373-400.

Péquart, M., Péquart, S.-J., 1930. Un gisement mésolithique en Bretagne : conférence du 28.02.1929. Bulletin de l'Association Lorraine d'Etudes Anthropologiques. 35-46.

Péquart, M., Péquart, S.-J., 1931. Sur une vertèbre humaine mésolithique percée d'une flèche. Association Française Pour l'Avancement des Sciences. 321-324. 
Péquart, M., Péquart, S.-J., 1933a. Découverte d'une nouvelle nécropole mésolithique à l'île d'Hoëdic. L'Anthropologie. 43, 646-647.

Péquart, M., Péquart, S.-J., 1933b. La civilisation mésolithique en Bretagne méridionale.

Découverte d'une nouvelle station à l'île d'Hoëdic (Morbihan). Association Française Pour l'Avancement des Sciences. 358-359.

Péquart, M., Péquart, S.-J., 1934. La nécropole mésolithique de l'île d'Hoëdic. L'Anthropologie. 44, 1-20.

Péquart, M., Péquart, S.-J., 1935. Kjökkenmödding et les sépultures de l'île d'Hoëdic (Morbihan), in: Congrès Préhistorique de France, Périgueux, XI ${ }^{\mathrm{e}}$ Session 1934. Edition de la société préhistorique française, Paris, pp. 505-517.

Péquart, M., Péquart, S.-J., 1954. Hoëdic, deuxième station-nécropole du Mésolithique côtier Armoricain. De Sikkel, Anvers.

Péquart, M., Péquart, S.-J., Boule, M., Vallois., H. 1937. Téviec : station nécropole mésolithique du Morbihan. Archives de l'Institut de Paléontologie humaine 18. Masson, Paris.

Pereira da Costa, F.A., 1865. Da existencia do homem em epocas remotas no valle do tejo. Primeiro opusculo. Noticia sobre os esqueletos humanos descobertos no Cabeço da Arruda. Lisboa.

Pickard, C., Bonsall, C., 2009. Some observations on the Mesolithic Crustaceans Assemblages from Ulva Cave, Inner Hebrides, Scotland, in: Burdukiewicz, J.M., Cyrek, K., Dyczek, P., Szymczak, K. (Eds.), Understanding the Past. Papers Offered to Stefan K. Kozlowski. Warsaw: Center for Research on the Antiquity of Southeastern Europe, University of Warsaw, pp. 305-313.

Pluciennik, M., 1998. Deconstructing 'the Neolithic' in the Mesolithic-Neolithic Transition, in: Edmonds, M., Richards, C. (Eds.), Understanding the Neolithic of north-western Europe. Cruithne Press, Glasgow, pp. 61-83.

Poissonnier, B., Kayser, O., 1988. Les bois de cerfs mésolithiques de Beg-er-Vil à Quiberon $\begin{array}{lllll}\text { (Morbihan). } & \text { Revue } & \text { archéologique de }\end{array}$ https://doi.org/10.3406/rao.1988.918.

Price, T. D., Brown, J.A., 1985. Aspects of Hunter-Gatherer Complexity, in: Price, T. D., Brown J. A. (Eds.), Prehistoric hunter-gatherers: The emergence of cultural complexity. Academic Press, New York, pp. 3-20.

Reimer, P.J., Bard, E., Bayliss, A., Beck, J.W., Blackwell, P.G., Bronk, Ramsey C., Buck, C.E., Cheng, H., Edwards, R.L., Friedrich, M., Grootes, P.M., Guilderson, T.P., 
Haflidason, H., Hajdas, I., Hatté, C., Heaton, T.J., Hoffmann, D.L., Hogg, A.G., Hughen, K.A., Kaiser, K.F., Kromer, B., Manning, S.W., Niu, M., Reimer, R.W., Richards, D.A., Scott, E.M., Southon, J.R., Staff, R.A., Turney, C.S.M., Van der Plicht, J., 2013. IntCal13 and Marine13 radiocarbon age calibration curves 0-50,000 years cal BP. Radiocarbon, 554, 1869-1887.

Ribeiro, M.C., 1884. Les kioekkenmoeddings de la Vallée du Tage, in: Congrès International d'Anthropologie et d'Archéologie Préhistoriques. Compte rendu de la neuvième session, Lisbonne, 1880. Typographie de l'Académie Royale des Sciences, Lisbonne, pp. 279-290.

Rigaud, S., 2011. La parure : traceur de la géographie culturelle et des dynamiques de peuplement au passage Mésolithique-Néolithique en Europe ". Thèse de l'Université de Bordeaux I, spécialité : Préhistoire et géologie du quaternaire, Bordeaux.

Roche, J., 1972. Le gisement mésolithique de Moita do Sebastiao. Muge, Portugal. IArcheologia. Instituto de Cultura, Lisbonne.

Roche, J., 1983. Les origines de l'industrie de l'amas coquillier de Moita do Sebastião (Muga, Portugal), in: Kozlowski, J. K., Kozlowski, S. K. (Eds.), Les changements, leurs mécanismes, leurs causes dans la culture du 7e au 6e millénaire av. J-C. en Europe. Archaeologia Interregionalis, pp. 165-174.

Roksandic, M., Jackes, M., 2014. The skeletal assemblage and burial ritual at the site of Cabeco da Amoreira: The 1960s excavations by Veiga Ferreira and Roche, in: Roksandic, M., Mendonça de Souza, S., Eggers, S., Burchell, M., Klokler, D. (Eds.), The Cultural Dynamics of Shell-Matrix Sites: Diverse Bioarchaeological Perspectives. University of New Mexico Press, Albuquerque, pp. 113-129.

Russell, N.J,. Bonsall, C., Sutherland, D.G., 1995. The exploitation of marine molluscs in the Mesolithic of western Scotland evidence from Ulva Cave, Inner Hebrides, in: Fischer, A. (Ed.), Man and Sea in Mesolithic. Oxbow, Oxford, pp. 273-288.

Sassaman, K. E., 2004. Complex hunter-gatherers in evolution and history: a north-american perspective. Journal of archaeological research, 12-3, 227-280.

Sanz de Sautuola, M., 1880. Breves apuntes sobre algunos objetos prehistóricos de la Provincia de Santander, in: Madariaga de la Campa, B. (Ed.), Escritos y Documentos. Institución Cultural Cantabria, Santander, pp. 69-104.

Schulting, R.J., 1996. Antlers, bone pins and flint blades: the Mesolithic cemeteries of Téviec and Hoëdic. Brittany. Antiquity. 335-350. https://doi.org/10.1017/S0003598X00083319. 
Schulting, R.J., 2005. Comme la mer qui se retire : les changements dans l'exploitation des ressources marines du Mésolithique au Néolithique en Bretagne, in: Marchand, G. Tresset, A. (Eds.), Unité et diversité des processus de néolithisation sur la façade atlantique de l'Europe (7-4ème millénaires avant J.-C.). Mémoire de la Société Préhistorique Française, XXXVI, pp. 163-171.

Schulting, R.J., Richards, M.P., 2001. Dating women becoming farmers: new paleo dietary and AMS dating evidence from the Breton Mesolithic cemeteries of Téviec and Hoëdic. Journal of Anthropological Archaeology. 20, 314-344.

Schulting, R.J., Tresset, A., Dupont, C., 2004. From Harvesting the Sea to Stock Rearing Along the Atlantic Façade of North-Western Europe. Environmental Archaeology. 9, 143 154. https://doi.org/10.1179/146141004790734478.

Straus, L.-G., 1981. On marine hunter-gatherers: a view from cantabrian Spain. Munibe. 33, 171-173.

Straus, L.-G., 2004. Transitions: into and out of "Mesolithic" adaptations along the Atlantic Facade of Europe and beyond, in: González Morales, M., Clark, G.A., (Eds.), The Mesolithic of the Atlantic Façade. Anthropological Research Papers. 55, Arizona States University, pp. 249-260.

Straus, L., Clark, G., 1986. La Riera Cave Stone Age hunter-gatherer adaptations in northern Spain. Anthropological Research Papers 36, Arizona State University.

Taborin, Y. 1971. La parure en coquillage de l'Epipaléolithique au Bronze ancien de France. Doctoral Dissertation, Université de Paris I, Paris.

Taborin, Y. 1974. La parure en coquillage de l'Epipaléolithique au bronze ancien en France. Gallia Préhistoire. 17-1, 101-179. https://doi.org/10.3406/galip.1974.1463.

Testart, A., 1982. Les chasseurs-cueilleurs ou l'origine des inégalités. Société d'Ethnographie, Paris.

Tresset, A., 2000. Early Husbandry in Atlantic Areas. Animal Introductions, Diffusions of Techniques and Native Acculturation at the North-Western Fringe of Europe, in: Henderson, J.C. (Ed.), The Prehistory and Early History of Atlantic Europe. Papers from session held at the European Association of Archaeologists Fourth Annual Meeting in Göteborg 1998. BAR International Series 861, Oxford, pp. 17-32.

Tresset, A., 2002. De la mer au bétail en domaine atlantique : unité et diversité des processus d'apparition de l'élevage à la marge nord-ouest de l'Europe. Anthropozoologica. 36, 13 36. 
Tresset, A., 2003. French Connections II: Of cows and men, in: Armit, I., Murphy, E., Nelis, E., Simpson, D. (Eds.), Neolithic settlement in Ireland and Western Britain. Oxbow, Oxford, pp. 18-30.

Tresset A., 2005a. L'avifaune des sites mésolithiques et néolithiques de Bretagne (5500 à 2500 av. J.-C.) : implications ethnologiques et biogéographiques. Revue de Paléobiologie. $10,83-94$.

Tresset, A., 2005b. La place changeante des bovins dans les bestiaires du Mésolithique final et du Néolithique d'Armorique et des régions adjacentes, in : Marchand, G., Tresset, A. (Eds.), Unité et diversité des processus de néolithisation sur la façade atlantique de l'Europe (VIe-IVe millénaires avant J.-C.), Mémoire Société préhistorique française 36. Société préhistorique française, Paris, pp. 273-286.

Verger, F., 2005. Marais et estuaires du littoral français. Belin, Paris.

Woodman, P.C., 2009. Ireland's place in the European Mesolithic: why it's ok to be different, in: McCartan, S., Schulting, R., Warren, G., Woodman, P. (Eds.), Mesolithic Horizons, Papers presented at the 7th International Conference on the Mesolithic in Europe, Belfast 2005. Oxbow Books, Oxford, pp. xxxvi-xlvi.

Yesner, D., 1980. Maritime Hunter-Gatherers: Ecology and Prehistory. Current Anthropology. 21-6, 727-750.

Zvelebil, M., 1986. Hunters in transition -Mesolithic societies of temperate Eurasia and their transition to farming. Cambridge University Press, Cambridge.

\section{Acknowledgements}

We dedicate this paper to our friend Anne Tresset, talented archaeozoologist whose ideas have always inspired us over the years. The author would like to thank the volunteers who contributed to the excavation and to the sieving of shell middens. This article was corrected by Louise Byrne thanks to funding from AMI "Rewriting" of the MSHB (Maison des sciences de l'homme en Bretagne) and from the International Research Network PrehCOAST Coast-inland dynamics in prehistoric hunter-gatherer societies". 


\section{Declaration of interests}

$\bigotimes$ The authors declare that they have no known competing financial interests or personal relationships that could have appeared to influence the work reported in this paper.

$\square$ The authors declare the following financial interests/personal relationships which may be considered as potential competing interests: 